Notre Dame Law School

NDLScholarship

Journal Articles

Publications

1997

\title{
The Good of Marriage and the Morality of Sexual Relations: Some Philosophical and Historical Observations
}

John M. Finnis

Notre Dame Law School, john.m.finnis.1@nd.edu

Follow this and additional works at: https://scholarship.law.nd.edu/law_faculty_scholarship

Part of the Family Law Commons, Natural Law Commons, and the Sexuality and the Law Commons

\section{Recommended Citation}

John M. Finnis, The Good of Marriage and the Morality of Sexual Relations: Some Philosophical and Historical Observations, 42 Am. J. Juris. 97 (1997).

Available at: https://scholarship.law.nd.edu/law_faculty_scholarship/873

This Article is brought to you for free and open access by the Publications at NDLScholarship. It has been accepted for inclusion in Journal Articles by an authorized administrator of NDLScholarship. For more information, please contact lawdr@nd.edu. 


\title{
Forum: Sexual Morality and the Possibility of "Same-Sex Marriage"
}

\section{THE GOOD OF MARRIAGE AND THE MORALITY OF SEXUAL RELATIONS: SOME PHILOSOPHICAL AND HISTORICAL OBSERVATIONS}

\author{
JOHN FINNIS
}

I

Aquinas organized his account of the morality of sexual relations around the good of marriage. The good of marriage is one of the basic human goods to which human choice and action are directed by the first principles of practical reason. ${ }^{1}$ Sex acts $^{2}$ are immoral when they are

1. ST I-II q. 94 a. $2 \mathrm{c}$ and Eth. V.12 n. 4 [1019] list the conjunctio maris et feminae as a basic human good, and make it clear that here Aquinas has in mind the Roman law definition of marriage, which he quotes directly at the outset of his own early treatise on marriage, in IV Sent. d. 26 q. 1: "the mating of man with woman, which we call "marriage"" [maris et feminae conjunctio, quam nos matrimonium appellamus\}. References to Aquinas' works in this article:

Eth. SententiaLibri Ethicorum (Commentary on Aristotle's Nicomachean Ethics) 1271-

2. References (e.g. IX.7 n. 6 [1845]) are to the book, lectio, and paragraph number followed by a reference to the paragraph number in Raymundi M. Spiazzi, O.P. (ed.),

S. Thomae Aquinatis In Decem Libros Ethicorum. Aristotelis ad Nicomachum Expositio, Turin: Marietti, 1949.

In Eph. Commentarium super Epistolam ad Ephesios (Commentary on Paul's Letter to the Ephesians). References (e.g. 5.3 ad v.12 [416]) are to the book, lectio, and biblical verse, followed by the paragraph number in Raphael Cai, O.P., S. Thomae Aquinatis Super Epistolas S. Pauli Lectura, 8th ed., Turin \& Rome: Marietti, 1951.

Mal. Quaestiones Disputatae de Malo (De Malo: Disputed Questions on Evil).

Quodl. Quaestiones de Quolibet (Disputed [Debated] Quodlibetal [Random] Questions) 1256-9 (VII-XI) and 1269-72 (I-VI, XII).

ScG Summa contra Gentiles (A Summary of Theology "Against the Unbelievers") 1259-64/5. References are by book (I, II, III, IV) and paragraph number (n.).

Sent. Scriptum super Libros Sententiarum Petri Lombardiensis (Commentary on the Sentences [Opinions or Positions of the Church Fathers] [Handbook of Theology] of Peter Lombard [c. 1155]) I, 1253-4; II, 1254-5; III, 1255-6; IV, 1256-7. References are by book (I, II, III, IV), distinction (d.), question (q.), anticle (a.) and sometimes to the response (solution) to a sub-question (sol.).

ST Summa Theologiae (A Summary of Theology): I, 1265-8; I-II, 1271; II-II, 1271-2; III, 1272-3. References (e.g. I-II q. 2 a. $2 c$ \& ad 2) are to the four parts (first, first-ofthe-second, second-of the-second, third), question (q.), article (a.), corpus (c) [i.e. the 
"against the good of marriage," as unreasonable, ${ }^{4}$ unnatural). Considered precisely as kinds of morally bad sex - rather than as, say, unjust (as rapes and some other morally bad sex acts obviously also are)-wrongful sex acts are more seriously immoral the "more distant" they are from marital sexual intercourse." Aquinas' account

body of Aquinas's response], reply (ad 1, ad 2, etc.) to a particular, numbered objection (obj. 1, obj. 2, etc.), and/or to the provisional reply sed contra (s.c.).

Supp. Supplementum (A Supplement to [or rather, a partial completion of ST, posthumously and anonymously constructed from passages of IV Sent.).

Ver. Quaestiones Dispulatae de Veritate (De Verilate: Disputed [Debated] Questions on Truth).

2. By "sex act" and "(have) sex" I shall here always mean an act or sequence of performances engaged in with the intention or willingness that it secure orgasmic sexual satisfaction for one or more person doing or participating in the act. This is substantially the concept employed also by Aquinas: see ST II-II q. 154 a. 4; Mark Jordan, The Invention of Sodomy in Christian Theology (Chicago: The University of Chicago Press, 1997), 156, is entirely mistaken in claiming that Aquinas has "no other way of distinguishing the class of acts, pleasures, and sins as venereal" than by "relation to the teleology of reproduction," and "no category of the sexual apart from animal teleology." Aquinas, like the moderns ("us") with whom Jordan is striving to contrast him, has a straightforward concept of sexual (= "venereal") acts: those intended to arouse or experience sexual pleasure, viz. the kind of intense pleasure associated with orgasm-i.e. with the ejaculation of male or female seminal fluids: ST II-Il q. 152 a. Ic \& ad 4; q. 154 a. $4 c \&$ ad 2; IV Sent. d. 33 q. 3 a. 1 ad 4 \& ad 5; on female semen and orgasm see nn. 51, 115, and 127 below. Note that the definition I have given of "sex act" is morally neutral: morally good marital intercourse is one kind of sex act. (And see my Aquinas: Moral, Political, and Legal Theory (Oxford: Oxford University Press, 1998), ch. V.4 at n. 47.) The critique of my views offered by Carlos A. Ball, "Moral Foundations for a Discourse on Same-Sex Marriage: Looking Beyond Political Liberalism," Georgetown Law Joumal 85 (1997) 1872 at 1912-19, derails right from the start by groundlessly assuming that the equivalent definition of "homosexual sex act" given in my "Law, Morality, and 'Sexual Orientation, '" Notre Dame Law Review 69 (1994) 1049 at 1055 "contains its own built-in moral disapprobation."

3. This phrase (contra bonum matrimonii) is used in relation to adultery, including adultery with the spouse's consent (ST II-II q. 154 a. 8 ad 2 \& ad 3; IV Sent. d. 33 q. 1 a. 3 sol. 1 (= Supp. q. 65 a. 3) ad 5). The concept is close to the surface in the discussion of many kinds of sexual misdeed in ScG III c. 122; see text and note 115 below.

4. Aquinas' moral arguments never run from "natural" to "therefore reasonable and right," but always from "reasonable and right" to "therefore natural." As he says, "moral precepts are in accord with (consequuntur) human nature because they are the requirements/ prescriptions of natural reason (cum sint de dictamine rationis naturalis)": IV Sent. d. 2 q. I a. 4 sol. I ad 2; likewise, repeatedly, ST I-Il q. 71 a. 2c (e.g. "virtues...are in accordance with human nature just insofar as they are in line with reason; vices are against human nature just insofar as they are against the order of reasonableness"); also q. 94 a. 3 ad 2; q. 18 a. Sc; q. 78 a. 3c; II-II q. 158 a. 2 ad 4 ("the activity [of the capacity for anger] is natural to human beings just insofar as it is in accordance with reason; insofar as it is outside the order of reasonableness it is contrary to human nature"); Finnis, Natural Law and Natural Rights (Oxford: Oxford University Press, 1980), 35-6. See also text and notes 58-65 below.

5. IV Sent. d. 41 a. 4 sol. $3 c$ ("...secundum quod magis distat a matrimoniali concubitu"); see also Mal q. 15 a. Ic. Andrew Koppelman's claim (p. 87) that Aquinas 
of what it is to act sexually "against the good of marriage" leaves a good deal to be clarified. But he did deploy a line of thought that lawyers and philosophical theologians had articulated in the preceding century, and that brilliantly illuminates the ways in which sex acts, even when performed consensually between spouses, can be against the good of marriage and therefore unreasonable.

Germain Grisez's 1993 treatise on sex, marriage, and family life clarifies large tracts of sexual morality which Aquinas' account left more or less obscure. For it shows how various kinds of sex act, even when performed (e.g. as solitary masturbation, or homosexual sodomy) by unmarried people who have no intention of marrying, violate the good of marriage. ${ }^{6}$

In 1994 I published an article which explored the reasons why "Plato and Socrates, Xenophon, Aristotle, Musonius Rufus, and Plutarch, right at the heart of their reflections on the homoerotic culture around them, make the very deliberate and careful judgment that homosexual conduct (and indeed all extramarital ${ }^{7}$ sexual gratification) is radically incapable of participating in, actualizing, the common good of friendship." The article then considered why homosexual conduct is "never a valid, humanly acceptable choice and form of life" and is (rightly) "repudiated as destructive of human character and relationships." The primary reason I summarized thus:

it treats human sexual capacities in a way which is deeply hostile to the self-understanding of those members of the community who are willing to commit themselves to real marriage in the understanding that its sexual joys are not mere instruments or accompaniments to, or mere compensations for, the accomplishment of marriage's responsibilities, but rather enable the spouses to actualize and experience their intelligent commitment to share in those responsibilities, in that genuine self-giving. 9

regarded homosexual acts as "uniquely monstrous" is false: see ST II-II q. 154 a. 12; ScG III c. 122; similarly mistaken is his claim (if he intends it, as the context suggests, to refer to degree of gravity) that Grisez holds that the considerations which show homosexual acts to be wrong "equally condemn other nonmarital sexual acts." Grisez, The Way of the Lord Jesus vol. 2 Living a Christian Life (Quincy, IL: Franciscan Press, 1993), 654 (a page cited more than once by Koppelman), explicitly says that homosexual acts are generically "more unreasonable" than fornication. Andrew Koppelman, "Is Marriage Inherently Heterosexual?," Am. J. Juris. 42 (1997) 51. Parenthetical numbers in my article are references to the pages of his article.

6. Grisez, Living a Christian Life, 633, 649. Grisez's treatise is theological, but the relevant philosophical arguments and considerations can be distinguished and detached by careful analysis, and my own discussion in this article is restricted to philosophical and historical considerations and method.

7. In that article I used "extra-marital" to refer to all nonmarital sex acts; in the present article I shall use "extramarital" to refer to adulterous sex acts, a sub-class of "nonmarital" sex acts.

8. Finnis, "Law, Morality, and 'Sexual Orientation,"' at 1065.

9. Ibid. at 1069 . 
To emphasize the point, I added:

...the deliberate willingness to promote and engage in homosexual acts....treats human sexual capacities in a way which is deeply hostile to the self-understanding of those members of the community who are willing to commit themselves to real marriage. ... [It] is, in fact, a standing denial of the intrinsic aptness of sexual intercourse to actualize and in that sense give expression to the exclusiveness and open-ended commitment of marriage as something good in itself. ${ }^{10}$

Thus, like Aquinas and Grisez, I argued that approval of homosexual and other nonmarital sex acts is not simply nonmarital, in the sense of being utterly incapable of consummating or actualizing the human good of marriage, but actually "contrary to" or "violative of" that good."

Andrew Koppelman now offers a critique of Aquinas, Grisez, and me which overlooks this central argument entirely. ${ }^{12}$ He constructs for Aquinas a sex ethics based on alleged principles-about respect for "the natural order of things" or "normality"- -which are remote from those which Aquinas actually employs in his account of why some sex acts are morally unacceptable. He says (p. 77) 'the fatal gap in [Aquinas'] argument...is his failure to show what human good will be frustrated by homosexual conduct," but he never mentions Aquinas' treatment of the good of marriage or Aquinas' thesis that morally bad sex is contrary to that good. Or my own similar thesis. Similarly, while quoting many snippets from Grisez, Koppelman neglects to mention Grisez's primary thesis and argument. He foists on Grisez and me an argument about sex and pleasure (and the "experience machine"), an argument he constructs largely from bits and pieces of earlier philosophical writings (mostly of mine) in which sexual morality was not the issue. Like the scholars on whom he heavily relies-John Noonan and John Boswell-Koppelman is unaware that Aquinas' treatment of the radically different ways in which sex can be for pleasure sheds much light on the whole question of the good of marriage and the ways in which that good can be violated. ${ }^{13}$

10. Ibid. at 1069-70.

11. I also indicated that nonmarital, including homosexual, sex acts are immoral because they violate inner integrity and entail preferring an illusory instantiation of a basic human good to a real instantiation of that or some other human good: ibid. at 1069 . These elements of my position are developed further in Patrick Lee and Robert P. George, "What Sex Can Be: Self-Alienation, Illusion, or One-Flesh Unity," Am. J. Juris. 42 (1997) 135. I shall here say little or nothing more about them. But note that Koppelman's statement of the argument about disintegrity (Koppelman, p. 87, text between nn. 143 and 144) misapprehends it.

12. Koppelman, supra n.5.

13. When I wrote "Law, Morality, and 'Sexual Orientation'". I was by no means as keenly aware of the power of Aquinas' treatment of the good of marriage as I became in writing chapter V.4 of my Aquinas: Moral, Political, and Legal Theory (1998). 
A good many parts of Koppelman's essay I shall scarcely mention. No one need be detained by its reflections on the supposed incompatibility between evolution ("Darwin") and Aquinas' fitth argument for the existence of God; ${ }^{14}$ or by its adoption of Ron Garet's home-made theology of sacramental grace; or by its fragmentary review of the psychological literature on the effects that choices to engage in homosexual conduct have on character, family, ${ }^{15}$ and society; or by its creditably tentative re-run of the manifestly sophistical argument that laws acknowledging or defining marriage as a relationship between a man and a woman ${ }^{16}$ discriminate

14. With Koppelman p. 71 at $\mathbf{n} .94$ compare the statement of Darwin's friend and colleague, the leading American botanist and evolutionist Asa Gray, in 1874: "Let us recognize Darwin's great service to Natural Science in bringing back to it teleology; so that, instead of Morphology versus Teleology, we shall have Morphology wedded to Teleology." And Darwin's response: "What you say about Teleology pleases me especially, and I do not think any one else has ever noticed the point." For the sources and illuminating discussion of related sources and issues, see Leon R. Kass, "Teleology and Darwin's The Origin of Species: Beyond Chance and Necessity?" in Stuart F. Spicker (ed.), Organism, Medicine, and Metaphysics: Essays in Honour of Hans Jonas (Dordrecht and Boston: D. Reidel, 1978), 97120 at $97-8$.

15. Koppelman more than once cites Charlotte J. Patterson, "Children of Lesbian and Gay Parents," Child Development 63 (1992) 1025 as his authority for stating that "studies...have found" e.g. that "children raised by same-sex couples develop just as well as...children of opposite-sex couples" (p. 58, n. 34; p. 65, n. 66). The slenderness of the bases for this "finding" is stated even in Patterson's own article at pp. 1028-9 and 1036:

systematic empirical study of these issues is just beginning.... Studies in this area [scil. gay fathers] are still rather scarce.... the preponderance of research to date has focussed on children who were born in the context of heterosexual marriages, whose parents divorced, and whose mothers have identified themselves as lesbians. ... Two reports (McCandlish, 1987; Steckel, 1987) have focused on children born to lesbians in the context of ongoing lesbian relationships. Of [sic] the many other ways in which children might come to be brought up by lesbian or gay parents (e.g. through foster parenting, adoptive parenting, coparenting, or multiple parenting arrangements), no systematic research has yet appeared. ... most [studies] compare children in divorced lesbian mother-headed families with children in divorced heterosexual mother-headed families. ... A particularly notable weakness of existing research has been the tendency in most studies to compare development among children of a group of divorced lesbian mothers, many of whom are living with lesbian partners, to that among children of a group of divorced heterosexual mothers who are not currently living with heterosexual partners.

As was the case with divorce's now well-documented bad effects on children, it may take some decades for sociological research to catch up with realities which were always predictable and predicted by reflective and morally-sensitive common sense.

16. In this article I shall not be considering what the law is or should be. For much information and good sense on those issues, see David Orgon Coolidge, "Same-Sex Marriage? Baehr v. Miike and the Meaning of Marriage," South Texas L. Rev. 38 (1997) 1-119. 
irrationally on grounds of sex. ${ }^{17}$ One can, however, learn something from observing how comprehensively the traditional ethics of sexuality can be, and is, misstated by scholars who criticize it in the name of more (Boswell and Koppelman) or less (Noonan) radical reform. In sections II and III, I shall consider that critique. In section IV, I shall sketch an argument restating the relationship between that traditional ethics of sexuality and the good of marriage. In section V, I shall say something about same-sex imitations or caricatures of marriage.

In his immensely influential book Contraception, which manifests a familiarity with Aquinas' works far greater than Boswell's or Koppelman's, John Noonan claimed that for Aquinas it is a sin, "at least venial," to seek pleasure in marital intercourse. ${ }^{18}$

It is in fact quite clear that Aquinas thought it entirely reasonable to be interested in and motivated by the prospect of enjoying the pleasures of marital sexual intercourse. ${ }^{19}$ Noonan is well aware of this. So he holds

17. The sophism is easily detected once one realizes that "discriminates on grounds of sex" is shorthand primarily for "discriminates against women (and in favor of men) on the grounds that they are female, or against men (and in favor of women) on the grounds that they are male." Of course, anti-discrimination laws characteristically embrace (sometimes justifiably) certain secondary forms of "discrimination," viz. distinction between persons on the basis or grounds of certain characteristics (other than maleness or femaleness) which de facto are possessed only or disproportionately by males (or, as the case may be, females). But even this secondary sense of "discrimination on grounds of sex" still has nothing to do with distinguishing the relationship between husband and wife from all other forms of relationship on the ground that only a husband-wife relationship can be marriage (and that marriage deserves a kind and degree of legal support which other partnerships do not). Koppelman goes some way towards recognizing and conceding this in his remarks about "the underlying purposes of sex-discrimination law" and in his evident unease in the face of the thought "that discrimination against gays has nothing to do with sexism as such," in Koppelman, "Three Arguments for Gay Rights," Michigan L. Rev. 95 (1997) 1636 at 1662 and n. 113. Arguments that distinguishing marriage from heterosexual or homosexual concubinage is per se discriminating in favor of men are a sign of desperation.

18. John T. Noonan Jr., Contraception: A History of Its Trealment by the Catholic Theologians and Canonists (Cambridge, Mass.: Harvard University Press, 1965 and 1986), 250 (the view that "labeled the intention to seek pleasure in intercourse as venial...was held steadily by...Thomas, On the Sentences 4.31.2.3"); 294 ("Why was it, according to Thomas, at least venial sin to seek pleasure?"); 295.

19. See IV Sent. d. 31 q. 1 a. 1 ad 1 (= Supp. q. 49 a. 1 ad 1): as hunger makes us interested in eating (ad excitandum ad comestionem\}, so divine providence has attached pleasure to marital intercourse to interest us in engaging in generative types of act ad excitandum ad actum... \}; d. 26 q. 1 a. 4 obj. 5 \& ad 5 (= Supp. q. 41 a. 4 obj. 5 \& ad 5); Supp. q. 65 a. 4 ad 3 (cf. IV Sent. d. 33 q. 1 a. 3 sol. 2 ad 3). Morally good marital intercourse shares with other sex acts the choice and purpose (propositum) of orgasmic pleasure \{talem delectationem\}: see ST II-II q. 152 a. 1c. See also Ver. q. 25 a. 5 ad 7: when what is rightly desired has been settled by reason [scil. intercourse between us as soon as appropriate, as an act of marital fides], then even though one's bodily appetite is aroused 
that Aquinas simply contradicts himself (within a couple of pages!) on the propriety of seeking sexual pleasure. ${ }^{20}$ No such contradiction exists. The only text which Noonan cites to support his claim that Aquinas rejects sexual pleasure as a legitimate motive for marital intercourse is a text concemed, quite explicitly, with a rather different question: Is it wrong to make sexual pleasure one's sole motive in or for intercourse? ${ }^{21}$ The answer is, Yes. But only after a careful explanation of what it means to make pleasure one's exclusive motive. In relation to intercourse between spouses, that means one or other of two kinds of thing, says Aquinas. At best, one is not interested in or concerned with anything about one's spouse other than what one would be concerned with in a prostitute or gigolo; 22 in other words, one's sexual activity is seeking, not to express affection for or commitment to the one person who is one's spouse, but to get pleasure. It is de-personalized, and de-maritalized. There is a worse kind of case: one is so concerned with pleasure alone that one would be willing to engage in intercourse with some other attractive and available person, even someone not one's spouse. In this case the pleasure-driven de-personalizing and demaritalizing has gone so far that one's sex acts, even though they are in fact with one's spouse, are a kind of adultery, a serious violation of the good of marriage.

That is what Aquinas means by having sex precisely "for the sake of pleasure," i.e. solely for the sake of pleasure-for pleasure alone. His condemnation of such de-personalized and de-maritalized sex acts is completely compatible with his constant thesis that pleasure is a proper,

towards it there is nothing wrong with all that (tametsi sensualitas in id feratur, nullum erit peccatum]. Universally, "part of the fullness of the morally good is that one is moved to the good [with which a particular act is concerned] not only by one's will but also by one's sense appetites, one's flesh": I-II q. 24 a. 3c. And universally, "it is natural to us as rational animals that our power of desiring ([vis] concupiscibilis) be drawn towards what is sensually enjoyable (in delectabile sensus\} in line with reasonable order (secundum ordinem rationis\}": Mal. q. 4 a. 2 ad 4 [or: ad 1].

20. Contraception, 294 ("A contradiction existed between [Aquinas'] statement [Sent. 4.31.1.1] that God intends sexual pleasure to be an inducement and [his] statement [Sent. 4.31.2.3] that to act for sexual pleasure in marriage is evil."). Noonan offers to resolve the contradiction for Aquinas by suggesting that Aquinas should, on his own principles, abandon the first of these two [alleged] statements (which, Noonan oddly thinks, "was a departure from Aristotelian principle")! (Ibid.)

21. IV Sent. d. 31 q. 2 a. 3 (= Supp. q. 49 a. 6): the question in issue is defined at the beginning of the article as to what extent it is sinful "for someone to have intercourse with his wife, not intending the [or: a] good of marriage but ONLY pleasure [solam delectationem]." The reference to pleasure being the sole motivation is repeated throughout the discussion (see objs. 1, 2 and 4), though occasional references (e.g. obj. 3) to "for the sake of pleasure" show that the latter phrase is, in this context, to be taken narrowly, as equivalent to "for the sake only of pleasure, and without any interest in a marital good."

22. IV Sent. d. 31 q. 2 a. 3 (= Supp. q. 49 a. 6) ad 1: "nihil aliud in ea [scil. uxore] attendit quam quod in meretrice attenderet." 
indeed providentially appointed, ${ }^{23}$ motive for engaging in marital intercourse. Moreover, Aquinas' objection to de-personalized sex has no exclusive connection with pleasure, and manifests no special suspicion of pleasure. For he makes it clear that there is the same kind of wrong-and venial or serious, depending on how far one's act is de-maritalizedwhenever one's motive for engaging in intercourse is solely one's health ${ }^{24}$ or solely "cooling off," i.e. the reduction of one's own temptations to extramarital sex. 25

At the end of his main discussion of this kind of sexual immorality, Aquinas says that in acts of such a kind ${ }^{26}$ one "becomes "all flesh'."27 A sign of Noonan's far-reaching misunderstanding of Aquinas' entire account of sex is his remark (citing this passage) that Aquinas

treats Augustine as his teacher on the effects of sexual acts. He repeats the Augustinian epigram that in coitus man "becomes all flesh."28

Even in Augustine, however, the "epigram" concerns not coitus (sexual intercourse), which might be morally good or bad, but immoral sex acts: in the relevant passage in Augustine the immorality is fornication (especially, though not only, as or with a prostitute); in Aquinas, as we have seen, it is having sex with one's spouse as if he or she were a prostitute. Aquinas is perfectly clear: an authentically marital act of sexual intercourse is an act which, so far from rendering the spouses "all flesh," enhances their spiritual friendship with God. ${ }^{29}$ Such a misreading bodes ill for Noonan's

23. See note 19 above.

24. IV Sent. d. 31 q. 2 a. 2 (= Supp. q. 49 a. Sc) ad 4.

25. Ibid. ad 2.

26. IV Sent. d. 31 q. 2 a. 3 (= Supp. 9. 49 a. 6c) ad 4 :"in illo actu"; illo ("that") refers back to the objection, which defines the kind(s) of act in question as having intercourse with one's spouse "simply from sexual desire [or lust]" (sola libidine).

27. Contraception, 254. The internal quotation, which Noonan does not identify, is a stock medieval paraphrase of Augustine, Sermon 162 (al. frag. 3 n. 2), PL 38 col. 887 ("sed simul totus homo dici possit quod caro sit"), reflecting on why St. Paul in I Corinthians 6: 18 considers fornication to be a sin against one's own body.

28. Id. (the citation to ad 3 is a slip for ad 4).

29. IV Sent. d. 26 q. 1 a. 4c (= Supp. q. 41, a. 4c), a text never cited by Noonan, though it is fundamental, and includes a treatment of precisely the same problem as the later "all flesh" passage in Supp. 49,6. The whole matter is clear enough already (about forty years before these writings of Aquinas) in the gloss on Lombard by Alexander of Hales (whose work influenced Aquinas), IV Sent. d. 31 para. $10 \mathrm{f}$ (in relation to the meritoriousness of the marital act): "Though there is more unity in marital sexual intercourse than there is in fornication, there is no more carnality; so it is in deeds of lust, and not in the marital act, that 'man is all flesh"' ("In opere coniugali maior est unio [than in formication], quia unitas fidei et unitas sacramenti. Sed licet maior sit unitas, non tamen maior carnalitas; unde in opere libidinoso est homo totus caro, non autem in opere matrimoniale."). There is another passage where Aquinas employs the phrase "totus homo caro efficitur": IV Sent. d. 27 q. 3 a. I sol. Ic (= Supp. q. 66, a. Ic). Here what "makes one all flesh" is again not coition as such, still less authentically marital intercourse, but concupiscentia, the lust that incites 
understanding of Aquinas' sex ethics-indeed, of the whole tradition's.

Noonan's mistakes about pleasure as a motive are tightly linked with a more important thesis-and a more profound mistake. Aquinas, he says:

is defending the proposition that only a procreative purpose excuses coitus.... Coitus is naturally ordained for procreation, and nothing else. ${ }^{30}$

Koppelman, too, claims that for Aquinas "reproduction is...the only good that humans can pursue by the use of their sexual faculties" and desires for other goods are unnatural. But the very passage cited here by Noonan is sufficient to dispose of both Noonan's and Koppelman's claims. For it is in fact defending the contrary proposition: that marital intercourse is made right not only by the spouses' interest in the good of offspring (procreation) but also, and alternatively, by their interest in the good Aquinas calls fides-i.e. by either of

those two goods of marriage which [unlike the third good of (Christian) marriage, sacramentum] concem the act of marital intercourse. And so, when spouses come together [sexually] in the hope of procreating children $O R$ so that they may give each other what each is entitled to, which is a matter of fides, they are [each] completely free from wrongdoing. ${ }^{31}$

Indeed, in the same passage, Aquinas adds that if spouses have intercourse simply out of the natural impulse to have children, their act is morally "imperfect unless it is further directed towards some marital good." 32 Coitus, in other words, is naturally ordained for marriage, and nothing else;

someone to bigamy; that lust can be completely absent from those who are content with one wife and need not be present in those who legitimately remarry after the death of their spouse (see IV Sent. d. 42 q. 3 (= Supp. q. 63) a. Ic; in the special context of the medieval canonlaw rules about restrictions on priestly ordination being considered in Supp. q. 66 a. 1, even a legitimate second marriage was, however, treated (i) as being defective as a sign of Christ's unity with his Church, and similarly (ii) as, in the order of public signs, suggestive of a lack of freedom from the lust which "makes one all flesh," even if in fact in the given case no such lust were present).

30. Contraception, 242, citing Sent. d. 31 q. 2 a. 2 [Supp. q. 49, a. 5]. Jordan, Invention of Sodomy, 156, makes the same fundamental mistake, similarly associated with his own (similar) mistakes $(143,156)$ about Aquinas' views on intensity of sexual pleasure : see n. 52 below.

31. Sent. d. 31 q. 2 a. 2 c [Supp. q. 49 , a. 5c].

32. Supp. q. 49, a. 1 ad 1 . The preceding sentence, taken out of context, can be misread as asserting that marital intercourse must be directed, by actual or habitual intention, to offspring considered as pertaining to a marital good. But Aquinas says this only because he is considering the case of spouses who happen to be moved by the raw natural reproductive instinct \{motus naturae); these spouses, he is saying, will be acting to some extent wrongly unless they integrate their instinct with the intelligible, marital good of having and raising a child to be educated towards human fulfilment. 
and marriage, as Thomas constantly teaches, is ordained for something-another particular marital good-besides procreation. ${ }^{33}$

What is this marital good, which Aquinas considers a good and sufficient motive for marital intercourse even when the marital good he calls offspring (proles: procreation) is not intended or possible? What is it, for example, that enables a married couple, as Aquinas says, to return "with joy" (laetantes) to marital intercourse after a period of abstinence? It is the good known in the tradition which Aquinas is following as fides. That is the word for faith or fidelity, but Aquinas' explanations of it in the marital context make it plain that it cannot safely be translated "fidelity." For "fidelity" in modern English signifies the real but negative good of not being unfaithful - of not committing adultery. But fides in Aquinas is also a motive. Indeed, in a sequence of passages partly overlooked and partly misunderstood by Noonan, ${ }^{34}$ Aquinas indicates that it is the motive which

33. For a contemporary argument in the spirit of Aquinas that it is wrong for even married people to engage in sexual intercourse or other acts purely for the purpose of conceiving a child and apart from the good of marriage itself, see Robert P. George and Gerard V. Bradley, "Marriage and the Liberal Imagination," Georgetown Law Joumal 84 (1995) 301 at 305 n. 19 (on Henry VIII).

34. IV Sent. d. 31 q. 1 a. 2 and q. 2 a. 2 (= Supp. q. 49 a. 2 and a. 4 ). Citing the first of these two passages, Noonan, Contraception, 285, claims that Aquinas

says of "matrimony" - not of marital intercourse-that... "On the part of the act itself, it is good in its genus in that it falls on due matter; and thus there is set as a good of marriage fidelity, whereby a man approaches his own wife, and not another woman." This analysis would seem to have been transferable to the act of intercourse. (On the Sentences 4.31.1.2 [= Supp. 49, 2]).

Indeed, the analysis is thus transferable. According to Noonan (id.), however, Aquinas (without ever discussing the matter) assumed that it was not transferable, that "the analysis was not applicable to coitus." But in reality, in Supp. q. 49 a. 4 (on the page after Supp. 49, 2) Aquinas asserts clearly that it is transferable-that the analysis of marital "goods" applicable to marriage is precisely applicable to sexual intercourse and, when so applied, establishes why marital intercourse is decent, good, morally right, and meritorious. This second passage is dealing precisely with the question "whether the marital act can be made completely right by the aforesaid goods" i.e. the marital goods identified in a. 2 and discussed in a. 2 and a. 3. The corpus of the reply in a. 4 answers, without equivocation, that "the aforesaid goods"-i.e. the very ones named in a. 2 (the article quoted by Noonan)-make the act good, i.e. entirely free from wrong. "This is what fides and offspring do in the marriage act (in actu matrimonii\}, as indicated above \{ut ex dictis patet\}." "Above," as editors agree, means a. 2. So Noonan has not only overlooked a. 4c but also misread a. $2 c$, for he understood a. $2 c$ 's phrase "on the part of the act itself" to refer only to the act of marrying, whereas it in fact extended to the act of marital intercourse (although that act is not the primary topic of a. 2, as it is of a. 4): Surprisingly, a. $4 \mathrm{c}$ is never cited in Contraception, which cites the almost adjacent articles preceding $-q .49$, a. 1 (twice), a. 2 (twice) -and the adjacent articles following-a. 5 (four times), and a. 6 (five times). The book even cites a. 4 ad 3-the reply to the third objection in the article in question-a couple of inches from the decisive text. But that text-the subject-matter, the question, and the body of the response-is passed over in complete silence. So too is the 
is present in every genuinely marital act of intercourse, whereas other motives such as procreation are sometimes present and sometimes not.

Fides is the disposition and commitment of each of the spouses to "cleave to \{accedere\}"35-precisely, to be maritally and thus bodily united with-the other and no other person. ${ }^{36}$ Besides the negative commitment not to be maritally or in any other way sexually united to anyone other than one's spouse ("fidelity"), fides even more basically includes a positive commitment and willingness, a reason for action. ${ }^{38}$ This is nothing less than the key to understanding Aquinas' account of sexual morality. Fides is, indeed, the characteristic proximate object(ive) or "appropriate matter about which \{debita materia [circa quam]\}" we are engaged when we choose to engage in marital intercourse, even on those occasions when we also have explicitly or implicitly the hope of procreating. ${ }^{39}$ This positive fides is the willingness and commitment to belong to, and be united in mind

immediately preceding article, a. 3, which also teaches what Noonan is denying, viz. that for Aquinas fides is a good which pertains not only to marriage itself but also ad usum matrimonii, i.e. to the act of marital intercourse. And, as we have seen above, when he cites a. 5 he claims it says the exact opposite ("only for procreation") of what it in fact says ("either for procreation or for fides").

35. Accedere has a wide range of meanings around "approach" and "adhere to", and importantly includes "have sexual intercourse with" (e.g. as in fornication: I-II q. 73 a. 7c; ScG III c. 122 n. 1 [2947]). Its meaning in respect of marital fides is clearly very closely analogous to its meaning in one of Aquinas' central theological propositions, viz. that it is by fides that one can adhere to (accedere) God (IV Sent. d. 45 q. 1 a. 2 sol. Ic (= Supp. 69 a. 4c); ST I-II q. 113 a. 4c; II-II q. 7 a. 2); and it is virtually synonymous with the adhaerere by which man and woman leave their respective parents and "cling/cleave to each other and become two in one flesh" (Genesis 2:24; Matthew 19:5): see ST II-II q. 26 a. 11c \& ad 1 \& ad s.c. [4].

36. IV Sent. d. 31 q. 1 a. 2 c (= Supp. q. 49 a. 2c) (see fn. 39 below); In I Cor. 7.1 ad v. 2 [318].

37. In true, central-case marriage, this commitment is completely open-ended in the sense that it excludes any sexual act with anyone other than one's spouse during his or her whole lifetime.

38. IV Sent. d. 31 q. 1 a. 2 ad 3 (= Supp. q. 49 a. 2 ad 3): "as the promise involved in marriage includes that each party will not go to \{accedere ad\} anyone else's bed, so too it includes this: that they will give each other due bodily cooperation in marital intercourse \{quod sibi invicem debitum reddant\}-and this latter is the more basic \{principalius\}, since it follows precisely from the mutual power which each confers on the other. And so each [of the two obligations, positive as well as negative] is a matter of fides."

39. IV Sent. d. 31 q. 1 a. $2 c$ (= Supp. q. 49 a. 2c): the act [of marital intercourse] is a morally good kind of act because it has an appropriate object, namely the fides by which a man cleaves to his wife and to no other woman [and a woman to her husband and no other man] [actus... est bonus in genere ex hoc quod cadit supra debitam materiam; et sic est fides, per quam homo ad suam accedit, et non ad aliam) (for the translation of supra debitam materiam see II Sent. d. 36 a. 5c; Mal. q. 2 a. 4 ad $5 \&$ ad 9, a. 6 c \& a. 7 ad 8, q. 7 a. Ic, \& q. 10 a. Ic; ST I-II q. 20 a. 1 \& a. 2 ; and see IV Sent. d. 31 q. 1 a. Ic \& a. $2 c$ (= Supp. q. 49 a. $4 c$ \& a. Sc), where what is said in IV Sent. d. 31 q. 1 a. $2 c(=q .49$ a. $2 c)$ about the nature and good of fides in relation to marriage itself is shown to be equally and explicitly applicable to the "marital act" of intercourse. 
and body with, one's spouse in the distinct form of societas and friendship $^{40}$ which we call marriage. ${ }^{41}$

This societas is a unique type of relationship; it is unified by its dual point \{finis\}: the procreation, nurture, and education of children, and the full sharing of life in a home. ${ }^{42}$ It is a companionship \{societas\} which should, Aquinas thinks, be "the greatest friendship, for they are united to each other not only in the act of bodily uniting in sexual intercourse \{camalis copulatio\}, which even among lower animals creates a kind of delightful \{suavis: sweet) societas, but also in mutual help (mutuum obsequium \} in sharing together in the whole way of life of a household fad totius domesticae conversationis consortium\}."

40. IV Sent. d. 41 q. 1 a. 1 sol. 1c (= Supp. q. 55 a. 1c). Eth. VIII.12 nn. 18-24 [171924] explains in terms of friendship (amicitia) the whole justice, usefulness, pleasure \{delectatio in actu generationis\}, and delight \{amicitia iucunda) in shared virtue which can be found in a good marriage with its division of complementary roles. IV Sent. d. $33 \mathrm{q} .1$. a. Ic (= Supp. q. 65 a. 1c) recalls this treatment when identifying fides as one of the two natural goods and ends of marriage. So fides is essentially marital friendship.

41. IV Sent. d. 33 q. 1 a. Ic $\&$ a. 3 sol. 3 c (=Supp. q. 65 a. Ic $\&$ a. 5c).

42. IV Sent. d. 27 q. 1 a. 1 sol. Ic (= Supp. q. 44 a. 1c): marriage is oriented to "some one thing (ad aliquod unum\}," but the one thing is two things, each radically unifying and mutually reinforcing as, together, the point of marriage: una generatio et educatio prolis and una vita domestica. These two "ends" of marriage define it, but there are other benefits intrinsic to it (other "secondary" ends besides mutual help); one of these is the multiplication of friendship by non-incestuous marriages which link two families: IV Sent. d. $\mathbf{4 0}$ (= Supp. q. 54) a. 3c. But the most important or intrinsic of these supplementary secondary ends or benefits is "the healing of one's desires (remedium concupiscentiae)": d. 33 q. 2 a. 1 (= Supp. q. 67 a. 1) ad 4. This is not a matter of simply providing sexual release; on the contrary, desires which are simply "given an outlet" only grow in strength (ST II-II q. 151 a. 2 ad 2; a. 3 ad 2; IV Sent. d. 2 q. 1 a. 1 sol. 2 c; d. 26 q. 2 (= Supp. q. 42) a. 3 ad 4). Rather, and crucially, it is a matter of integrating sexual desire with reason, which is what one does when one chooses intercourse in order to actualize and experience the good of marriage, i.e. for the sake of begetting children and/or of marital fides. When sex is thus made marital by integration with the marital goods \{bona matrimonii\} it is "healed" by being given intelligent meaning, and then the satisfaction it can give does "restrain" the desire which now is directed by reason(s) (ratione ordinatur) : d. 26 q. 2 (=Supp. q. 42) a. 3 ad 4. Desire so "restrained" by integration with reason can issue in satisfaction (pleasure) of the most intense kind: ST I q. 98 a. 2 ad 3.

43. ScG III c. 123 n. 6 [2964]. On the tight link between conjugal friendship/love \{amicitia\} - the mutual love or even love affair (mutua amatio\} between spouses-and that mutual help in life which is the marital benefit peculiar to the spouses, see IV Sent. d. $26 \mathrm{q}$. 2 (= Supp. q. 42 ) a. 2 c; d. 29 q. 1 a. 3 sol. 2 (= Supp. q. 47 a. 4 ) ad 1. On the tight link between mutual help and the good of offspring (such that the former can be regarded as a secondary end implicit in the latter), see IV Sent. d. 31 q. 1 (= Supp. q. 49) a. 2 ad 1. On the love \{dilectio\} that properly exists between spouses-the strongest of all forms of love between human beings-see also Il-II q. 26 a. Il c; In Eph. 5.9 ad v. 29 [328]. On marital intercourse (understood always as a kind of continuation, expression, and experiencing of the common commitment to a shared and, where possible, procreative life) as a cause of marital friendship, see IV Sent. d. 41 a. 1 sol. Ic (= Supp. q. 55 a. 1c); as a cause of love \{amor ex commixtione\}, ST II-II q. 154 a. 9c; as a primary motive for the love between 
So, fides is a motive, a reason, for many cooperative acts intrinsic or incidental to a sharing in the "whole life" of the marital household. As a rational motive for choosing to participate in an act of marital intercourse it is simply, we can say, the intended good of experiencing and in a particular way actualizing, ${ }^{44}$ and enabling one's spouse to experience and in a particular way actualize, the good of marriage - of our marriage precisely as our being bound, ${ }^{45}$ and belonging, to each other in such an exclusive and permanent cooperative relationship. ${ }^{46}$ Each of us is entitled to the other's cooperation in such acts, provided there is no reason ${ }^{47}$ for abstaining. So, truly marital intercourse is literally an act of justice, of giving each other what he or she can reasonably expect to be given. ${ }^{48}$ And that does not prevent it being also an act of love. ${ }^{49}$ It is an act which we can enter into with joy \{laetantes $;^{50}$ the fact that it can give the greatest of all ${ }^{51}$ bodily pleasures \{delectatio intensissima\} in no way makes it

spouses, II-II q. 26 a. 11 ad s.c. [4]. For Aquinas' remarkable analysis of the passionate effects of love, an analysis implicitly but manifestly on the paradigm of spousal love as a fitting cause of marital intercourse, see I-II q. 28 a. Sc. On beauty as an appropriate occasion of sexual attraction which can appropriately lead to considering marriage; such marriages can be good ones (and outlast bodily beauty): III Sent. d. 2 q. 2 a. 1 sol. Ic.

44. Note that to say that marital intercourse actualizes marriage does not imply that a marriage, having been consummated by such intercourse, cannot be very appropriately and amply actualized in many other ways as well.

45. See ScG IV c. 78 n. 5 [4123]: fides, by which man and wife are bound to each other [sibi invicem obligantur\}.

46. Because marriage is a type of relationship unified and specified by a single, basic human good, it makes sense even when one aspect of that complex good happens to be unattainable. So a man and a woman past the age of child-bearing can marry, and the integration of their sexual desires by the good of marital fides makes their marital sexual intercourse reasonable and morally good: IV Sent. d. 34 a. 2 (= Supp. q. 58 a. 1) ad 3.

47. E.g. the health of either party: IV Sent. d. 32 (= Supp. q. 64) a. 1 ad 1 \& ad 2. Of course, the two-sided good of marriage itself provides many reasons, intelligible in themselves without invention, for spouses to abstain from sexual intercourse, e.g. when either of them is disinclined or unwell, or they lack the time or privacy appropriate, or when abstaining for a time will intensify mutual satisfaction, and so forth.

48. IV Sent. d. 26 q. 1 (= Supp. q. 41) a. 4c; d. 31 (= Supp. q. 49) a. 2 ad 2; see also d. 38 q. 1 a. 3 sol. 2 (= Supp. q. 53 a. 1$)$ ad 3.

49. The spouses' mutual commitment (pactio) which fides serves is properly a bond of love \{vinculum amoris\} (In Is. 7 ad v. 14 line 436); indeed "spouse" is a word used to signify love (In Matt. 9 ad v. 15 [769]). Since fides is not merely negative but also positive, to speak of greater fides is to speak of greater love (fidelior amor): see ScG III c. $123 \mathrm{n} .8$ [2966]. See also n. 43 above.

50. In I Cor. 7.1 ad v. 5 [325]. Note: this thought-that spouses who have been abstaining will return to marital intercourse with joy-is Aquinas' own contribution, not suggested by the text on which he is there commenting; for other sources of the thought see ibid. ad v. 2 [319]; I-II q. 105 a. 4c (on Deuteronomy 24:5).

51. 11-II q. 152 a. 1c; \& see Quodl. XII q. 13 a. 1c; q. 14 a. un. c [1. 53]. Note, incidentally, that Aquinas, appealing to the testimony of the eleventh-century Persian polymath Avicenna, takes it for granted that in marital intercourse the woman is not infrequently moved inwardly by orgasmic pleasure so vehemently that the neck of her womb 
unreasonable; 52 there is nothing wrong at all with our welcoming assent to such pleasure in the marital act; 53 nor in our being motivated towards

temporarily opens up \{ex delectatione, ut avicenna dicit, movetur et aperitur\}: IV Sent. d. 31 a. $3 \mathrm{ex}$.

52. II-II q. 153 a. 2 ad 2; IV Sent. d. 26 q. 1 a. 3 ad 6 (=Supp. q. 41 a. 3 ad 6); d. 31 q. 2 a. 1 ad 3 (= Supp. q. 49 a. 4 ad 3); I-II q. 34 a. 1 ad 1. Jordan, The Invention of Sodomy, 143, states that, for Aquinas, "[t]he present intensity of venereal pleasure is a penalty of the Fall (153.2 ad 2, ad 3)"; he then says (id.) that for Aquinas the vice of "Iuxuria is an excess of venereal pleasure." The reader is thus invited to accept that Aquinas thinks that the vice in morally bad sex is that it is too intensely pleasurable; indeed, the very last words (p. 176) of Jordan's book are: "'Sodomy' is the nervous refusal of theologians to understand how pleasure can survive the preaching of the Gospel." But this is all wrong. Aquinas teaches quite plainly that no increase in the quantity or intensity of pleasure makes a kind of pleasurable act bad. Indeed, that is the unambiguous thesis of the first passage cited by Jordan (ST II-II q. 153 a. 2 ad 2): "the virtuous 'mean' [between too much and too little] is not a matter of quantity but of appropriateness to right reason. And so the abundance of pleasure given by reasonable sex acts is not contrary to the virtuous mean (et ideo abundantia delectationis quae est in actu venereo secundum rationis ordinato, non contrariatur medio virtutis\}." The "penalty of the Fall" which Aquinas goes on to speak of in that passage and in the other passage (ad 3) cited by Jordan is precisely not that sex acts are now too intensely pleasurable, but that we now find it difficult to integrate or harmonize our sexual desires and pleasure with reason's moderation. And this "moderation" is, again, not a matter of less (less intense) pleasure. Aquinas makes this as plain as could be in his full-dress treatment of the consequences of the Fall in ST I q. 98 a. 2 ad 3:

in the state of innocence [before the Fall] there would have been nothing of this kind [scil. the pleasure of coitus and the heat of desire] which would not have been moderated by reason-not that there would have been less of these pleasures of the senses, as some people claim (indeed, the sensory pleasure [of sex] would have been greater, in proportion to the greater purity of human nature and the greater sensitivity of human bodies [before the Fall]), but rather that desire, being regulated by reason, would not have pursued this sort of pleasure in such disordered ways (ita inordinate\}, and would not have clung to pleasure immoderately. And when I say "immoderately" I mean unreasonably (praeter mensuram rationis\}. For those who consume food "with moderation" do not have less pleasure in eating than gluttons do; it's just that their desire is less fixated on that sort of pleasure. And this is in line with Augustine's thought that what was incompatible with the state of innocence was not great quantities of pleasure (magnitudinem delectationis\} but rather the burning of lust, and confusion of mind and will (inquietudinem animi\}.

That passage is from one of Aquinas' late works; in one of his earliest he maintains the same position: before the Fall damaged humankind's inner harmony of feelings with reason (see ST I-II q. 82 a. 2 ad 2; In Rom. 5.3 ad v. 12 [416]), the pleasure given by sex acts would have been "much less disproportionate to rational control [than now]", but simply in terms of pleasure \{absolute\} "would have been greater pleasure": II Sent. d. 20 q. 1 a. 2 ad 2. Jordan's misreading of ST II-II q. 153 a. 2 ad 2 goes further, for according to that very text, the fact that marital intercourse is or can be so intensely delightful \{abundantia delectationis\} that it temporarily disables the spouses from thinking of spiritual matters ad spiritualia consideranda) does not make it morally defective. See likewise IV Sent d. 26 q. 1 (= Supp. q. 41 ) a. 3 ad 6; q. 2 a. 1 (= Supp. q. 49 a. 4) ad 3.

53. Mal. q. 15 a. 2 ad 17. 
such an act just by the prospect of giving and sharing in that delight as token of our marital commitment. 54

Once one sees that, for Aquinas, marital intercourse has an intelligible, rational point-the spouses' expression and actualization of their mutual commitment in marriage-one can readily see also that it followed inevitably, for Aquinas, that spouses act quite reasonably in seeking and taking pleasure in such intercourse. For throughout the whole order of things (as Aristotle had made abundantly clear) ${ }^{55}$ we find that reasonable, morally decent action tends to be stimulated and accompanied by, and certainly is perfected in, pleasurable fulfilment \{fruitio\}. ${ }^{56}$ Only when it is unhinged from consistency with practical reason's requirements does the pursuit of pleasure become morally defective.

\section{III}

The massive misunderstanding of Aquinas on sexual pleasure and on the goods which give reason for marital intercourse is tightly linked with another misunderstanding, which provides a primary and recurring theme of Koppelman's article. According to this misunderstanding or misreading (in Koppelman's version of it), Aquinas' sex ethics rests on the premise that one should not depart from "the patterns laid down in nature" or "what ordinarily and typically happens in nature" (p. 72); "any departure from the natural order is a defiance of the will of God" (p. 72). "A teleological account of this kind appears to be the only way to account for Aquinas' conclusion elsewhere [i.e. in ST II-II q. 154 a. 12] that homosexual intercourse is one of the worst vices of lust..." (p. 72)

Noonan, too, maintains that Aquinas' discussion of "unnatural" sexual vice has assumptions which

are made explicit in [ST II-II q. 154 a. 12].... the order of reason is strikingly contrasted with the order of nature. Nature is conceived in a special way as sacred and unchangeable. Fornication and adultery violate what "is determined by right reason." The sin against nature violates what is "determined by nature." Violation of this natural order is an affront to God, though "no other person is injured." .... The sharp distinction between acts that offend the natural order and acts that offend the rational order goes back to a distinction in types of natural law. ${ }^{57}$

This thoroughly misrepresents Aquinas' understanding of (i) immorality [sin], (ii) sexual immorality (a sub-class of immoralities), and (iii) "unnatural vice" (a sub-class of sexual immoralities). The first words in Aquinas'

54. See n. 19 above.

55. Hence Noonan's reference to "Aristotelian principle": see n. 20 above.

56. See e.g. ST I-II q. 31 a. 1, a. 3, a. 7.

57. Contraception, 239, 240 (emphasis added, here as elsewhere unless otherwise noted). 
treatment of sexual immoralities in Summa Theologiae are "immorality [sin], in human acts, is that which is against the order of reason." 58 The same point is made at the very beginning of his treatments of sexual immoralities in Summa contra Gentiles ${ }^{59}$ and De Malo. ${ }^{60}$ At the outset of his main treatise on sex and marriage he had already made the point, in terms of the requirements of "natural reason" (explicitly contrasted with animal nature). ${ }^{61}$ In Summa Theologiae Aquinas repeats the point again and again: "it pertains to the very essence of sexual vice \{luxuria\} that it exceeds the order and way of reason"; 62 "the immorality of sexual vice \{peccatum luxuriae\} consists in this: that one is not using sexual pleasure in line with right reason (non secundum rectam rationem). ${ }^{63}$ The vices against nature, which are Noonan's (and Koppelman's) concern, are introduced as the very first category to exemplify being "out of accord with right reason \{non convenire rationi rectae\}.

In the article immediately before the one on which Noonan and Koppelman focus, Aquinas again repeats the point that, in common with all other sexual vices, the vice "called against nature" is "repugnant to right reason \{repugnat rationi rectae\}."65 Then he adds that this sort of sexual vice, "OVER AND ABOVE THIS [first-mentioned repugnancy to reason], is ALSO repugnant to the natural order of sexual acts itself, the order appropriate to the human species (etiam, super hoc, repugnat ipsi ordini naturali venerei actus qui convenit humanae specie $\}., 66$ The article which Noonan and Koppelman cite (they both ignore all the other texts I have cited here) also begins by taking for granted what has already been interminably asserted, that unnatural sexual vice is vice because it offends right reason; as Aquinas will observe, other types of sexual immorality "transgress ONLY what is in line with right reason-but presupposing natural foundations \{principia\}."67 Unnatural sexual vice transgresses, he says, not only the requirements of right reason in relation to sex but also those requirements' very "presuppositions, determined by nature." 68

This idea-that setting aside the naturally given foundations or presuppositions of reasonable judgments about sex acts makes what is unreasonable particularly serious or far-reaching in its implications for character-is

58. ST II-II q. 153 a. 2 c. See also n. 4 above.

59. ScG III c. 122. Here the argument is not explicitly about the order of reason, but about what is "contrary to human good," and thus implicitly but necessarily unreasonable.

60. Mal. q. 15 a. Ic.

61. IV Sent. d. 26 q. 1. a.1c \& ad 1 (= Supp. q. 41 a. 1c \& ad 1).

62. ST II-II q. 153 a. 3c.

63. ST II-II q. 154 a. Ic.

64. Id.

65. ST II-II q. 154, a. $11 \mathrm{c}$.

66. Id.

67. ST II-II q. 154 a. $12 \mathrm{c}$.

68. Id. 
doubtless in need of further explanation. But the task of providing such a further explanation is not very urgent, since (as Noonan and Koppelman fail to observe) this whole article (q. 154 a. 12) is concerned, not with why unnatural vice is wrong-that was the subject of the previous article, unmentioned by our authors-but only with the comparative gravity of types of act already assumed to be wrong. As Grisez regularly makes clear in relation to his own work, factors which aggravate the wrongness of an immoral choice cannot be assumed to be factors which by themselves would be capable of making the choice immoral. ${ }^{69}$

Pursuing his mistaken view that Aquinas' sex ethics is founded on respect for given nature, rather than on respect for reason and the human goods to which reason directs our choosing, Noonan says that, according to Aquinas,

God, not neighbour, is offended by the sin [against nature]. This approach put enormous emphasis on the givenness of the act of insemination; the act was invested with a God-given quality not to be touched by rational control or manipulation..... the act seemed to be assigned the absolute value of God. ... the only person injured by the sin was God. ${ }^{70}$

But in exactly the same passages in De Malo, as Noonan acknowledges forty pages later, Aquinas "had based his case against lechery" [luxuria, sexual vice - certainly including homosexual and other acts popularly called "unnatural vice"] "on the ground that it impedes the good of offspring."71 And at the head of his little treatise on sex ethics in the Summa contra Gentiles (in a chapter often cited by Noonan, and partially quoted by Koppelman), Aquinas puts the statement (never mentioned in Contraception or by Koppelman) that "God is not offended by us (non enim Deus a nobis offenditur\} except when we act contrary to our good."72 Like it or not, Aquinas holds that all sexual immoralities \{omnes corruptiones luxuriae\} are "contrary to [love of] neighbour." H3 He does not dispute that simple fornication (not an "unnatural vice") does "no injury to" neighbour. ${ }^{74}$ But he $\operatorname{argues}^{75}$ that all sexual immoralities outside marriage are wrongs "against neighbour" because "against the good-of-generating-and-educatingoffspring." His thought, I believe, is that all sexual immoralities are against marriage, which (as he elsewhere argues explicitly) ${ }^{76}$ is the only reason-

69. See e.g. Living a Christian Life, 649, 658. Aquinas indicates this in other contexts: e.g. ST I-1l q. 20 a. 5; q. 73 a. 8. Thus: what makes lying always wrong does not always make it gravely wrong: ST II-II q. 110 aa. 3-4.

70. Contraception, 241, citing Mal. q. 15 aa. 1, 2 \& 3.

71. Ibid., 279.

72. ScG III c. 122 n. 2 . In c. $126 \mathrm{n}$. 1 he adds that "only those things that are opposed to reason are prohibited by divine law."

73. Mal. q. 15 a. 2 ad 4.

74. Ibid. obj. 4.

75. Ibid. ad 4.

76. E.g. ScG II c. 122 nn. 6-8. 
able context for having and raising children. The way in which unnatural acts, which can never themselves lead to children, offend against children, is explored below, ${ }^{77}$ when more of Aquinas' thought, overlooked by Noonan and Koppelman, has been set out.

Koppelman's dependence on Noonan comes to the surface in his quotation (pp. 74-5) and adoption of the passage of Contraception which claims that Aquinas

postulated as normal an act of coitus which led to generation. The norm was not derived from any statistical compilation. It was the product of intuition... Because the sexual act might be generative, and because generation was an important function, the theologian intuited that generation was the normal function. ... acts in which insemination was impossible... were unnatural; ...acts in which insemination was possible and conception resulted...were natural and normal; ... acts in which insemination was possible, but conception did not occur...were normal, ${ }^{78}$ but accidentally different from the norm. ${ }^{79}$

No text of Aquinas is cited in support of this, and none could be. ${ }^{80}$ Aquinas knew enough to know as well as we do that generation does not normally (i.e. on most occasions) follow insemination.

The other intellectual debt which Koppelman acknowledges in his critique of Aquinas is to John Boswell; Koppelman cannot imagine "how Aquinas could answer" Boswell's "devastating critique."81 And indeed it is not easy to reply to Boswell's account and critique of Aquinas: his incompe-

77. See text at $\mathrm{n} .112$ below.

78. The sense of the passage requires that this be regarded as a slip of the pen for "natural." Koppelman fails to see that the unamended train of thought (and the conclusion that there is an abnormal normality) makes no sense.

79. Contraception, 243.

80. Aquinas' reference to per accidens in Summa contra Gentiles c. 122, quoted on the preceding page of Contraception, has nothing to do with deviation from a statistical norm, or from a postulated or intuited (imagined!) norm according to which generation normally follows insemination. Per accidens is a phrase which gets its sense by contrast with per se or secundum se. In relation to human acts, the fundamental and usual meaning of this contrast is: [1] intended $v$. not intended-it has nothing to do with what does happen or typically happens. In c.122 the reference is a little wider than intended/unintended, and includes also [2] what in the nature of things is possible or not possible. But it also retains the primary sense of: [1] what, in the plans and intentions of an acting person, is to be left as possible or made to be impossible. Thus, in the emission of seed into the female reproductive tract where it is to be intentionally sterilized by a contraceptive jelly, the impossibility or reduced possibility of generation is [1] not incidental (per accidens) but intrinsic/intended (secundum se) (even if, in a given case, by chance, generation does follow). Equally, in the emission of seed into the mouth, the impossibility of generation is [2] not incidental (per accidens) but intrinsic (secundum se).

81. Page 74 at $n$. 102. The three reviewers cited in that note display little or no interest in defending Aquinas, and there is no need to search the world for efforts to do so. Boswell's work collapses as soon as one looks at the texts he cites from Aquinas. 
tence and deviousness are so pervasive that one hardly knows where to begin. So I shall take just the main passage cited by Koppelman, a passage which is in fact the highwater mark of Boswell's critique.

That passage (found in Boswell at pp. 324-5, cited by Koppelman at p. 74) examines, apparently rather closely, a portion of the Summa Theologiae which concerns, not morality, but the nature and types of pleasure. Aquinas is asking whether some pleasures are unnatural. He answers that there are two immediately relevant senses of "natural." In the first of these senses, something is natural to human beings just inasmuch as it is reasonable (rationally appropriate), and unnatural insofar as it is unreasonable. Boswell interjects that "it is very difficult to see how homosexuality violates "nature" in this sense, since "it was precisely the reason of man which proponents of gay sexuality had recently used to defend themselves" against the argument from natural design or "the physical compulsions of procreation." 82 His comment is absurd, since Aquinas was happy to use his own reason to evaluate allegedly rational arguments proposed by opponents, and does so about 10,000 times in the Summa Theologiae alone. By the end of the page which Boswell is considering, Aquinas will have made clear that he thinks the copulation of men with each other is "contrary to human nature" in this first sense, i.e. is unreasonable, so that the pleasure the sodomites take in it, being the pleasure of an unreasonable, morally wrong kind of act, is unnatural. Aquinas by then has also identified a second sense of "natural," viz. what is subrational, common to irrational animals as well as human beings, and/or what is not obedient to reason ${ }^{83}$ (like hunger, or sexual desire); in this second sense, human beings "naturally" take pleasure in sex acts. Boswell, having foolishly said that this distinction of senses is a contradiction, claims that in pointing to the second sense of "natural," Aquinas is "here providing the only substantiation for the claim that homosexual acts are 'unnatural'."84 In reality, Aquinas is not here arguing for or "substantiating" the claim at all; this portion of the work is not concerned to substantiate any claim in normative ethics. He is merely illustrating uses of the term "natural," in order to classify pleasures; where the classification turns on the reasonableness or unreasonableness of certain kinds of act, the argument about reasonableness is to be sought elsewhere (e.g. in the passages I mention in the next section).

But we now reach the high point of Boswell's efforts. He reports that Aquinas' discussion of natural and unnatural pleasures concludes with "the startling revelation following the second definition that homosexuality may in fact be quite 'natural' to a given individual, in either sense of the word"! After quoting a sentence in which Aquinas says that what is contrary to

82. Christianity, Social Tolerance, and Homosexuality, 324-5.

83. Boswell, ibid., 325, misunderstands this as claiming (absurdly) that sex and food "have nothing to do with thought"!

84. Ibid. 
human nature (in either sense) "may become natural to a particular man, owing to some defect of nature in him"-which Boswell wholly misreads as conceding that what in this sense is natural to these defective people is also natural in the sense of reasonable for them-Boswell concludes his description of the passage: "Although it may not be 'natural' for humans in general to be homosexual, it is apparently [according to Aquinas] quite 'natural' for particular individuals." He calls this a "circumstantial etiology of homosexuality," helps himself to the premise that "everything which is in any way 'natural' has a purpose, and the purpose is good,"85 and concludes triumphantly:

Since both homosexuality and femaleness occur "naturally" in some individuals, neither can be said to be inherently bad, and both must have an end. The Summa does not speculate on what the "end" of homosexuality might be, but this is hardly surprising in light of the prejudices of the day. It would seem that Saint Thomas would have been constrained to admit that homosexual acts were "appropriate" to those whom he considered "naturally" homosexual. ${ }^{86}$

Here incompetence and deviousness are inextricably entangled. What Aquinas means by "homosexual acts are natural to some people" is immediately evident from the parts of his paragraph which Boswell has completely hidden from his readers. 87 The kinds of "defect" (or rather comuption (comuptio\}) that make certain pleasures natural to some individuals can arise, says Aquinas, in different ways:

bodily defects/comuptions: e.g. sickness, as when sweet things taste bitter to people with a fever; or a bad physical constitution, as in the case of people who take pleasure in eating dirt or coal, etc.; or mental defects/corruptions, as in the case of men who, from habituation [or: convention/upbringing [propter consuetudinem\}] take pleasure in eating people, or in copulating with brute beasts or with other men, or in other things of that sort, which are not in line with human nature. ${ }^{88}$

85. Ibid., 327. Here Boswell is (or leaves his readers) blissfully unaware of the distinctions between metaphysical goodness (e.g. strength of the rapist-strangler's hands) and moral goodness, and between different senses of nature (not all explored in the passage he is considering). He overlooks Aquinas' view (quite coherent with the rest of Aquinas' work) that e.g. some people do and others do not have a "natural inclination towards certain sins" (ST J.Il q. 78 a. 3c), and that "There is in us all a natural inclination towards what is appealing to bodily feelings against the good of practical reasonableness (contra bonum rationis\}" (Mal. q. 16 a. 2c).

86. Ibid., 327 and n.87.

87. Boswell's pages are decorated with extensive quotations of lengthy passages, in Latin. Here the quotation (both in English and Latin) is drastically truncated, for a reason which (as I am now indicating) is obvious as soon as one looks at the sentence immediately following the one which Boswell quotes.

88. ST 1-II q. 31 a. 7c. 
Had Boswell accurately reported what Aquinas is here saying, readers would have greeted with derision his claims that Aquinas' "circumstantial etiology" of homosexuality gives Aquinas (or anyone) rational ground to consider homosexual acts appropriate and good. For the very same "etiology" would immediately give similar(ly good) ground for approval of cannibalism and bestiality.

Boswell completes his corrupt travesty of Aquinas a couple of pages later. He is now arguing that Aquinas' position on homosexual conduct was largely a result of "the pressures of popular antipathy," but also contributed to later hostility to homosexuality. So he makes the following accusation:

Aquinas played to his audience not simply by calling on popular conceptions of "nature" but also by linking homosexuality to behaviour which was certain to evoke reactions of horror and fear. He compared homosexual acts...with violent or disgusting acts of the most shocking type, like cannibalism, bestiality, [fn. cite to ST II-II q. 142 a. 4 ad 3] or eating dirt. ${ }^{89}$

To keep concealed from the reader what he had kept hidden in the passage about "circumstantial etiology" (when he was concerned more to co-opt Aquinas than to denounce him), Boswell is now citing not that earlier passage (with its undisclosed references to the unnatural pleasures of cannibalism, bestiality, eating dirt, and homosexual acts), but a passage hundreds of pages later, on the vices of surrender to pleasure. But Boswell lets slip his awareness of the earlier, suppressed passage: the reference to eating dirt occurs in the suppressed portion of that earlier passage, and not in the passage which he cites and quotes to show Aquinas' alleged crowd-pandering bigotry. And there is a further dishonesty in Boswell's accusation. As he knows perfectly well ${ }^{90}$ - but conceals from all those readers who have not memorized, or are unready to consult, the Nicomachean Ethics-Aquinas takes his linking of cannibalism, bestiality, and homosexual acts (along with the reference to eating dirt) from Aristotle; the linkage conveys not the result of medieval popular prejudice but the opinion apparently ${ }^{91}$ held by a great pagan philosopher in the midst of a homoerotic culture.

89. Christianity, Social Tolerance, and Homosexuality, 329.

90. See ibid., 324 at n. 76, where Boswell states that "the extent to which this discussion" [viz. I-II q. 31 a. 7-the passage whose content he partially concealed] "is indebted to Nicomachean Ethics 7.5 is often overlooked by editors."

91. See Aristotle, Nicomachean Ethics VII 1148b15-31; also Politics I 1252a33-9, II 1262a32-9 (imperceptively or evasively discussed in Martha C. Nussbaum, "Platonic Love and Colorado Law," Virginia L. Rev. 80 (1994) 1515 at 1586 n. 307); Finnis, "Law, Morality, and 'Sexual Orientation," at 1061. Nussbaum's claim (at 1585; likewise 1589) that $N E$ 1148b15-31 "was.central in the dispute between Professor Finnis and me" is false; it was at all times Plato whose work and modern interpretation was of primary concem to me and central to my critique of Nussbaum's remarkable evidence in the trial of Evans $v$. Romer, 63 Empl. Prac. Dec. (CCH) \$42,719 (14 December 1993); and see n. 109 below. 
Aquinas' reasons for judging certain types of sex act wrongful neither depend upon nor even include the lines of argument which Koppelman, Noonan, and Boswell ascribe to him. His reasons are concerned rather with the preconditions for instantiating, and the ways of disrespecting, the good of marriage, viz. the way of life made intelligible and choiceworthy by its twin orientation towards the procreation, support, and education of children and the mutual support and amicitia of spouses who, at all levels of their being, are sexually complementary. How, then, is this good violated by nonmarital sex acts, including even the sex acts of someone who perhaps could never marry?

\section{IV}

The answer to that question can begin by looking forward to Grisez's treatment of the same question. Grisez takes the vocabulary of his discussion largely from the Second Vatican Council's teaching on marriage. Speaking of acts of marital intercourse, the Council said:

Expressed in a manner which is truly human, these actions signify and foster that mutual self-giving by which spouses enrich each other with joyful and grateful hearts. 92

The concept of self-giving, as used in this passage, is obviously closely related to Aquinas' concept of marital fides as a positive motive for bodily union in marital intercourse: devotedness to this unique spouse and commitment to this exclusive community and sharing of life intended to be ended only by death. ${ }^{93}$ Accordingly, Aquinas' concept of "giving to each other what is [sexually] due or appropriate \{sibi invicem debitum reddere\}" is substantially equivalent to Vatican II's concept of spouses mutually giving themselves in sexual intercourse as an expression and fostering of marital communion. 94

In a sustained, penetrating argument of which Koppelman reports neither the principal conclusion nor all the premises, Grisez concludes that the good of marriage is violated not only by adultery (even when approved by the other spouse) and by a spouse's solitary masturbation (even when motivated by desire to avoid adultery), but also by all the intentional sexual acts of 49.

92. Gaudium et Spes (Pastoral Constitution on the Church in the Modern World) (1965),

93. In John Paul II's encyclical, Familiaris Consortio (1982), sec. 32, this is spoken of as "the total reciprocal self-giving of husband and wife." This way of putting the matter is not too happy, since iotal self-giving is literally impossible; so "total" must be explained as meaning no more (though no less) than a self-giving not impaired by any factor which ought not to be allowed to limit it. "Total" thus adds nothing to the explanation of the factors that can wrongfully impair marital commitment or its expression in sexual acts.

94. As Grisez notes: Living a Christian Life, 637, n. 166. 
unmarried persons. ${ }^{95}$ Among the argument's intermediate conclusions are the propositions defended now by Patrick Lee and Robert P. George, ${ }^{96}$ about the masturbatory choice of self-disintegrity, and the formicatory and sodomitic choice of an illusory intimacy and bodily communion. What I wish to explore here is the proposition proximate to Grisez's ultimate conclusion that choices of nonmarital sex violate the good of marriage: the proposition that by such choices one "damages the body's capacity for the marital act as an act of self-giving which constitutes a communion of bodily persons." 97 It is this damage which makes such acts violative of the good of marriage. ${ }^{98}$

Whatever this damage to the body's capacity is, it is not, of course, a matter of physiological damage. Rather, it is a damage to the person as an integrated, acting being; it consists principally in that disposition of the will which is initiated by the choice to engage in an act of one or other of the kinds in question. It is a damage which can essentially ${ }^{99}$ be eliminated by repentance (which can be formal-as e.g. in a religious context-or informal). So, to say that a choice "damages the body's capacity for selfgiving" is, I think, elliptical for: that choice deforms one's will in such a way that unless one reverses one's choice (repents), it disables one-precisely as a free, rational, sentient, bodily person-from engaging in a bodily act which would really express, actualize, foster, and enable one as a spouse to experience the good of marriage and one's own commitment (self-giving) in marriage.

One can begin to understand this kind of deformity of the will, and its consequences for the capacities of the whole person, when one considers cases of the kind which interested Aquinas more, it seems, than any other aspect of sexual ethics-cases in which one or both of the spouses having sexual intercourse with each other can fail to integrate the act with the good of marriage, or can violate the good of marriage. The cases of obvious violation are those in which one or both of the spouses would be willing, or prefer, to be engaged in the act with someone else. ${ }^{100}$ Such a spouse is conditionally willing to engage in this sex act with someone not his or her

95. Ibid. 633, 649. Although Koppelman makes twenty-eight citations to this volume, he fails to cite either of these key pages, though he cites e.g. p. 634 and p. 650.

96. See $n .11$ above.

97. Living a Christian Life, 650. See also 654 on the same implication of sodomy (and equally of heterosexual activities within or outside marriage which are deliberately made not open to new life).

98. For: "to damage an intrinsic and necessary condition for attaining a good is to damage that good itself. Thus, masturbators violate the good of marital communion by violating the body's capacity for self-giving": ibid., 650-1.

99. I say "essentially," because there can also be psychological effects which, not being simply in the will, but extending down into the subrational elements of the human makeup, may not be eliminated merely by the will's reversal in repentance.

100. See text above at $\mathrm{nn}$. 21-26. 
spouse. That is, if such another person were available and all the other conditions were in place, this spouse would-unless he or she had a change of mind-have sex with that other person. ${ }^{101}$ (But such an altemative is not here and now available, so the spouse thus conditionally willing to commit adultery engages instead in intercourse with his or her spouse-perhaps even enthusiastically, in view of the pleasure or other benefits.)

Let us call such a conditional willingness to engage in extra- (i.e. non-) marital sex acts consent to nonmarital sex. ${ }^{102}$

People who attend carefully to the content of the willing in question easily understand that if one in this sort of way is consenting to nonmarital sex, one cannot choose to engage in marital intercourse, i.e. cannot make one's intercourse with one's spouse an expression of fides, commitment, self-giving. One may-as many actual adulterers do-hope to do so, but even if the intimacy with one's spouse gives one the illusion of marital communion, the experience remains illusory. And if one's spouse detects one's divided will, he or she can readily recognize, experientially, that one's participation in intercourse is nonmarital (despite its having all the other characteristics of marital intercourse). In short: if one consents to engaging in extramarital sex acts, one's choosing to engage in a sex act with one's spouse cannot succeed in being an actualizing of marriage. One's performances in moving towards one's own and/or one's spouse's orgasmic satisfaction are incapacitated from expressing marital commitment because, by one's consent, one is (conditionally) willing to do the same kind of action with someone to whom one is not married. The only way one can restore one's capacity to express marital self-giving (commitment) by way of sexual intercourse is to negate-repent of - one's consent to any act of that kind.

We have been considering the consent to nonmarital sex which may shape and divide the willingness of a married person, where the consent-conditional willingness-bears on that person's own actions in the (hypothetical) here and now:

101. On conditional willing, see John Finnis, "On Conditional Intentions and Preparatory Intentions" in Luke Gormally (ed.), Moral Truth and Moral Tradition: Essays in honour of Peter Geach and Elizabeth Anscombe (Dublin: Four Courts Press, 1994), 163-176. The essential points explored and illustrated in that essay (in relation to many different types of eligible action) are (i) that the condition in conditional willing relates not to the willingness (which is actual, not merely possible or hypothetical) but to the proposal (course of action) chosen or consented to; and (ii) that a willingness to treat an option (not yet chosen) as a serious option is a state of willingness which in its moral significance is essentially equivalent to an actual choice of that proposal to do such-and-such if...

102. Consent here is not to be understood as some momentary act of will, but as a disposition which (like other will acts) lasts in the will unless and until reversed by being repudiated (repented of, formally or informally). 
A. "I am so keen on having sex now that if an attractive woman were available (and my wife were not here), I would have sex with her, right now."

That was the kind of case Aquinas regularly discussed. But the consent which is the core of morally significant conditional willingness is just as real-just as capable of shaping and dividing one's will-if it bears on one's actions in some other possible circumstances.

B. "I'm not interested in having sex with anyone other than my husband right now, but if he goes off to war, I might well have sex with an attractive man."

C. "While I'm married I'm not going to have extramarital sex, but if I weren't married, I'd try to have sex with someone attractive once a week, to keep fit."

Cases $B$ and $C$, too, are forms of conditional willingness. "If I were then and there interested, I would under certain circumstances choose to have nonmarital sex." The effect, the implication in the will of the person in question, is essentially the same as in Aquinas' case, case $A .^{103}$ If one seriously gives one's assent to any of the practical propositions A through $\mathrm{C}$, one is here and now approving and consenting to sex acts as nonmarital - one regards and consents to treating such nonmarital acts as a reasonable option-and therefore, as long as so consenting, one is disabled from choosing to engage here and now in sexual intercourse with one's spouse as genuinely marital intercourse expressing and actualizing marital self-giving or commitment. ${ }^{104}$

What if one's state of mind is a version of $\mathrm{C}$ in which "While I'm married I'm not going to have extramarital sex...." is reinforced by "...because I think it's immoral for a married person to have extramarital sex..."? Obviously one's will is then much less divided than A's or B's; one does not consent, even conditionally, to having nonmarital sex of any

103. This essential identity of the objects (the intelligible content) of the different acts, by different persons, referred to in each of the type-cases, A, B, and C (and D and E below) respectively, is an implication of the universality or universalizability of the reasons for action (however specific) on which one's will-a rational faculty-proceeds in all its acts, notwithstanding that the action itself consented to, chosen, and done is always -or always would be, if and when done-a particular.

104. Of course, the thought that any consensual and mutually pleasurable sex acts between adults are acceptable is not logically incompatible, in a straightforward way, with the thought that mutually pleasurable marital intercourse is also acceptable, indeed better, or with the thought that mutually pleasurable marital intercourse which succeeds in conceiving a child is even better. The relevant incompatibility only comes to light when one considers the conditions under which intercourse between spouses is genuinely marital, expressing and actualizing marital self-giving and commitment. 
kind while married, for one regards that as morally excluded. Still, one is willing to engage in sex acts outside marriage (e.g. one does not repent of having engaged in them before marriage, and/or is conditionally willing to engage in them nonmaritally when one's spouse is dead and gone). So one's will, in willing intercourse with one's spouse, does remain divided, impure, motivated in part by something other than fides. What is true of $\mathrm{A}$ remains true here, albeit less extensively and intensively: one's performances in moving towards one's own and/or one's spouse's orgasmic satisfaction cannot express the exclusiveness of marital commitment and marital communion, because one is here and now (albeit conditionally) willing to do that sort of action for motives other than the expression of marital commitment.

Now consider cases where one's thought is turned explicitly to the conduct of other persons, and where one deliberately approves those persons' conduct:

D. "While I'm married I'm not going to have extramarital sex. But I think it's quite OK for people who want to have extramarital sex to do it..."

E. 'While I'm married I'm not going to have extramarital sex. But I think it's quite OK for unmarried people to get sexual satisfaction in any way they like, consistent with being fair to others..."

Cases $D$ and $E$, too, are cases of conditional willingness. This is of course less obvious than in cases $B$ and $C$. The bare thought that conduct $X$ is permissible for people differently situated from me does not logically entail that I must have any interest, however tenuous and conditional, in doing $X$. But outside a legalistic morality of prohibitions and permissions, the thought "It's OK for them" will convey the judgment that the conduct in question has some value. Moreover, the thinking is by a person who, like almost every adult, has some interest in orgasmic sexual satisfaction; indeed, this person is positively willing to engage in behavior which culminates in such satisfaction, at least in marriage. So the thought that it is permissible and OK for certain other people to get such satisfaction by nonmarital sex acts becomes deliberate approval, i.e. a thought of the form: "If I were in their situation, I would be willing to get sexual satisfaction by nonmarital sex acts." 105 As in cases B and C, the thought is: "If I were then and there interested, I would under certain circumstances, and without having to

105. This is true, even if (the thought of) being in that situation is at present quite repugnant to me in my condition and circumstances. Here the argument goes beyond, while following the trajectory of, Aquinas, ST I-II q. 74 a. 8. 
violate or change any of my present moral beliefs, be prepared to choose to have nonmarital sex." 106 When that thought is conjoined with present interest in sexual activity and satisfaction, it constitutes a present, albeit conditional willingness which incapacitates one from willing sexual intercourse with one's spouse as genuinely marital intercourse.

Thus one's conscience's complete exclusion of nonmarital sex acts from the range of acceptable and valuable human options is existentially, if not logically, a precondition for the truly marital character of one's intercourse as and with a spouse. Deliberate approval ${ }^{107}$ of nonmarital sex acts is among the states of mind (understanding and willingness) which damage one's capacity to choose and carry out as marital even those actual sex acts which in all other respects are marital in kind. It is a state of mind which, even in those people who are not interested in marrying, is contrary to, and violative of, the good of marriage.

And just as a cowardly weakling who would never try to kill anyone, yet deliberately approves of the killings of innocent people in a terrorist massacre, has a will which violates the good of life, so even a person of exclusively and irreversibly homosexual inclination ${ }^{108}$ violates the good

106. Since the condition, "If I were then and there interested...", relates only to emotional disposition, there is still conditional willingness-consent-in the case where the person in $D$ and $E$ adds "... and if my wife died I'd probably give up sex...". Even in the case where the agent's disposition not to have sex outside marriage seems more strictly volitional, i.e. based on reasons (e.g. "Sex distracts me from my play-writing..."), the prioritizing is based on preferences which, not being required (or reasonably regarded as required) by reason, may be changed by choice. Where one has some interest in behavior of some kind (e.g. behavior inducing orgasmic sexual satisfaction), then, even if one's interest is at present trumped by some countervailing interest, one is conditionally willing to engage in acts involving that behavior unless one regards those kinds of acts as excluded by reason (i.e. as immoral).

107. On deliberate approval of others' acts (precisely as such-not merely in their beneficial effects or other morally accidental features) as a form of willing of such acts, see Grisez, The Way of the Lord Jesus vol. 1 Christian Moral Principles, 374, 376 (with the refinements and clarifications in ch. G.6-8); vol. 2 Living a Christian Life, 657 (ch 9.E.4).

108. It is worth noting, though nothing in this article turns on it, that such a person would be one of a very small minority of those-themselves a very small proportion of the whole population-who "have a homosexual orientation." Consider the statistics given in research relied upon (for other purposes) by Koppelman, "Three Arguments for Gay Rights," Michigan L. Rev. 95 (1997) at 1665, viz. Edward O. Laumann et al., Social Organization of Sexuality: Sexual Practices in the United States (Chicago: The University of Chicago Press, 1994): Table 8.3A on p. 311 shows that (in the large, representative sample of the American population surveyed in 1992) only about $6 \%$ of all men and $3 \%$ of all women ever have any same-sex sex partner, and of those who do, fewer than $10 \%$ have sex only with same-sex partners. The upshot is accurately summarized by the authors on p. 312: "since puberty, under 1 percent of all men ( 0.6 percent) have had sex only with other boys or men and never with a female partner .... Only 0.2 per cent of all women have had sex only with women." So the overwhelming majority of homosexually oriented people (Keynes, Stephen Spender, the Cambridge Soviet spies Guy Burgess, Donald Maclean, and Anthony Blunt, and numerous other figures in twentieth-century cultural, political, and literary history-and most of the "gays and lesbians" studied in the sociological surveys relied upon by Koppelman: see 
of marriage by consenting to (deliberately approving) nonmarital sex acts such as solitary masturbation. ${ }^{109}$ That is an implication of the logic of practical reason-the intelligible goods available to me for choice or rejection are human goods, good for anyone. Moreover, the "wrongs of thought" of cowardly weaklings who will never kill (or homosexuals-or heterosexuals-who will never marry) rather rarely remain without impact on their own behavior and on the thoughts and behavior of other people. Such approval makes real killings of innocents more likely, and approval of nonmarital sex acts contributes to the cultural climate in which actual marriages founder. The wrongness of such thoughts does not depend on any "calculus" of consequences, of course, but should not be written off as of

n. 15 above) are fully capable of heterosexual arousal and sex acts including marital intercourse. For some striking, if "anecdotal" confirmation of this and other relevant realities mentioned in this article, see Martin Duberman, "Dr. Sagarin and Mr. Cory: The 'Father' of the Homophile Movement," The Harvard Gay \& Lesbian Review 4 (1997) 7-14.

109. Koppelman (p. 88) n. 149 buttresses his mistaken assumption that Grisez has a "suspicion of bodily pleasures" by approvingly quoting the confession by Martha Nussbaum and Kenneth Dover that they cannot see any morally relevant difference between the senses (ways) in which swimming, hiking and masturbating "use the body for pleasure," and see nothing objectionable about any of them. Koppelman might have added that on the next page they seem to see nothing objectionable in "nonmarital sex of many types"- which types they conspicuously fail to delimit even in principle: Nussbaum, "Platonic Love and Colorado Law," Virginia L. Rev. 80 (1994) 1515 at 1649, 1650. In the same article (at p. $1562 \mathrm{n}$. 176) they each express themselves unable to find any reference to masturbation in the passage (rightly taken by Nussbaum, elsewhere, to be of crucial importance in Plato's whole theory of human good) in Plato's Gorgias at 494 where Plato's Socrates obliges the tough skeptic Callicles to admit that there are bad pleasures, by getting him to think first of stimulating one's own body's lower (scil. genital) regions, and thence of a whole range of shameful acts including getting pleasure by being sodomized, "and all those other shameful things besides." Insensitivity to obvious differences between some ways of using one's body in bodily activity, and to the fact that using the body to give orgasmic satisfaction (i) involves a focus on the desiring, experiencing self as subject and the body as instrument, and (ii) damagingly implicates one's capacity for giving bodily expression to marital commitment, results in literary/scholarly insensitivity to the awareness which Plato shares with countless others. On Nussbaum's shifting views (and explanations of those views) on the passage from the Gorgias, and on her reliability as a witness to ancient philosophy and modern scholarship on matters of sexuality, see Finnis, article supra n. 2 at 1055-62; more fully, Finnis, "'Shameless Acts' in Colorado: Abuse of Scholarship in Constitutional Cases," Academic Questions 7 no. 4 (1994) 10 at 19-41; also Robert P. George, "'Shameless Acts' Revisited: Some Questions for Martha Nussbaum," Academic Questions 9 no. 1 (1995) 24-42. On her Virginia L. Rev. article generally, see Finnis, "Law, Morality, and 'Sexual Orientation,'" Notre Dame J. of Law, Ethics \& Public Policy 9 (1995) 11 at $18.20 \mathrm{nn} .15-17$. On Nussbaum and Dover as interpreters of Plato on sex and marriage, see the important comment by R.E. Allen (whose outstanding capabilities as translator and philosophical commentator had been firmly attested by Nussbaum herself in commenting on volume 1 of his Yale University Press translation of Plato: see the cover of the paperback edition of that volume), in The Dialogues of Plato, vol. 2, The Symposium (New Haven: Yale University Press, 1991) at $46 \mathrm{n} .76,99-102$; on Plato's (and, it seems, Aristotle's) condemnation of homosexual sex acts, ibid. 17-18, 46 n. 76, 74-7. 
"no practical concern" to others, still less as a motiveless imposition upon the consciences of people who are unmarried and perhaps unmarriageable.

The argument I have been sketching is completed by turning back to consider the actually married, and the significance for good or evil of their states of mind. Without the possibility of truly marital intercourse the good of marriage is seriously impaired. Any willingness (no matter how conditional) to engage in nonmarital sex undermines, radically even when not perceptibly, ${ }^{110}$ one's marriage itself as a reality to be initiated, fostered, and preserved in and by clear-headed deliberation and the work of an alert and well-formed conscience. For it disintegrates the intelligibility of one's marriage: one's sex acts, understood from the inside (so to speak) as the bodily carrying out of choices each made in a certain state of mind (will), no longer truly actualize and make possible authentic experience of one's marriage; they are unhinged from the other aspects of the spouses' mutual marital commitment and project. And this unhinging or dis-integration threatens-nuns contrary to-both of the goods inherent in the complex basic good of marriage: ${ }^{111}$ not only the good of marital friendship and fides but also the good of procreation and of the children whose whole formation is so deeply benefited by the context of a good marriage. So any kind of assent - even if conditional-to nonmarital sex is unreasonable. (Indeed, all sexual immorality, all sexual wrong willing however conditional, is contrary to love of neighbor, perhaps most directly of children.) $)^{112}$ And because it is unreasonable, it is immoral, ${ }^{113}$ and therefore ${ }^{114}$ out of line with human nature.

110. Of course, in the real world of not too clear-headed people (all of us, to some extent), the disintegrative implications of some unintelligibility which renders an option (e.g. our being married while willing to perform nonmarital sex acts) more or less incoherent are often muffled or postponed by other factors, such as convenience, individual or cultural inertia, etc. But ethics is concerned not with what happens to happen but with options as such, and the conditions under which they are or are not fully reasonable. As the late twentieth century collapse of marriage suggests, irrationalities consented to, perhaps generations earlier, in individual wills (and the culture they shape) will very probably make themselves, sooner or later, rather extensively apparent in bad further effects.

111. Marriage is a complex but unified good inasmuch as its goodness as unitive is inseparable from its goodness as procreative (even where procreation is per accidens impossible). Aquinas' train of thought about marital and nonmarital sexual acts is one valid way of understanding and acknowledging this inseparability.

112. See Mal. q. 15 a. 2 ad 4; IV Sent. d. 33 q. 1 a. 3 sol. 2 (= Supp. q. 65 a. 4c). In respect of children, at least, the violation of neighbor love is an offence against justice. It would therefore be entirely within the proper authority of law and government to e.g. withhold state or federal funding from any school which teaches that (say) masturbation is morally acceptable.

113. To say that it is immoral does not mean that individuals who do acts of the relevant kind are subjectively morally culpable; their moral culpability may sometimes be much diminished by passion that fetters freedom and/or by confusion of mind (e.g. ideology, fantasy) that obscures rational deliberation towards choice. See Aquinas, ST I-11 q. 73 a. 5c \& a. 6 ad 2.

114. See $n .4$ above. 
Koppelman quotes three fragments from Aquinas' Summa contra Gentiles III c. 122. He is right to find the apparent train of argument puzzling and unsatisfying. But he has overlooked the general movement of the chapter as a whole, ${ }^{115}$ which points towards the necessity and goodness of the institution of marriage as the only acceptable framework for the generation and, ordinarily, the care of children. The succeeding three chapters explore the relationships between sex acts and marriage precisely as the maximal friendship (maxima amicitia) it needs to be if it is to be what it ought for children and their parents. ${ }^{116}$

But whether or not Aquinas did have it in mind, the train of thought I have sketched in this section (and earlier, much more briefly, in the article to which Koppelman is responding) ${ }^{117}$ establishes one important sense in which all nonmarital sex acts, even by the unmarried uninterested in marriage, are contrary to the good of marriage because contrary to the selfgiving in marital intercourse which is at the heart of marriage.

Near the heart of Koppelman's contentions is the claim ${ }^{118}$ that there is no morally significant difference between the marriage of a sterile

115. And he has partly hidden that movement from himself and his readers by omitting from the first passage (p. 73 at $n$. 99) a whole sentence that is a premise for that passage's penultimate sentence (beginning "Therefore"!), and that introduces the theme with which the chapter is eventually dominantly concerned (and which simply disappears from Koppelman's account of it): the human need not just for generation or procreation but for marriage. The omitted sentence is (in the translation used by Koppelman): "But man's generative process would be frustrated unless it were followed by proper nutrition, because the offspring would not survive if proper nutrition were withheld." The whole pages of $c .122$ which Koppelman ignores conclude that it is natural (in the defined sense: reasonable in view of human good) for a man to establish with a particular woman the lasting societas we call matrimonium, and that deliberate emission of semen (orgasm) outside marriage is contrary to human good and therefore wrong. (In reading ScG III c. 122 on emission of semen do not overlook the fact that Aquinas thought that in female sexual activity a kind of semen (albeit not a kind which is a biological component in generation) is pleasurably emitted in the female reproductive tract: see IV Sent. d. 33 q. 3 a. Ic (quoted in n. 127 below) \& ad 5; d. 41 q. 1 a. 1 sol. 4 ad 2; III Sent. d. 3 q. 5 a. Ic; ST III q. 31 a. 5 ad 3).

116. What Aquinas says in ScG III c. 122, and the much fuller reflections on marriage and sexuality in the passages of his Commentary on the Sentences which I have mentioned, suggested to me the train of thought I have pursued in this section. Aquinas would have restated the argument of those passages if he had lived to write his projected treatment of marriage in Part III of the Summa Theologiae-a treatment to which he repeatedly refers the reader of the passages on sex in ST II-II q. 154.

117. See nn. 8-11 above.

118. See p. 66, referring with approval to Stephen Macedo's claim that "the homosexual couple is, in fact, the moral equivalent of the infertile heterosexual couple." On p. 66 Koppelman claims that "Grisez never explains the purported disanalogy between the gay couple and the heterosexual couple.... Finnis has attempted to fill this gap..." But in fact, everything I said was little more than a condensation of Grisez's treatment of precisely this question: op. cit. supra n. 5 at $634,636,651-4$. 
couple $^{119}$ and some committed liaison of two persons of the same sex who together engage in sex acts. ${ }^{120}$ Any such claim is bound to fail, for reasons which I indicate in this section. One way of pointing to those reasons is this. The marriage of a sterile couple is true marriage, because they can intend and do together all that any married couple need intend and do to undertake, consummate, and live out a valid marriage. It cannot have the fullness that a fertile marriage can have, and in that respect is a secondary rather than a central-case instantiation of the good of marriage. But the committed liaison of two (why two?) persons of the same sex who together engage in sex acts is an artificially constructed type-case which is a secondary version of a central case radically different from the central case of marriage. Indeed, what is the central case of same-sex sexual relationships? Perhaps it is the anonymous bathhouse encounter, engaged in with a view to being repeated in another cubicle later that night. Perhaps it is a same-sex threesome or foursome between currently steady, committed friends. Who knows? What is clear is that in the account of sex and friendship which Koppelman offers there is nothing to show why a currently two-person same-sex liaison should have the exclusiveness-and-intendedpermanence-in-commitment that is inherent in the idea of marriage (including the marriage of a sterile couple).

Every married couple is sterile most of the time. ${ }^{121}$ Outside one or two remote tribes, that has always been well known, even when the limited periods of fertility in the female cycle were mislocated. Koppelman and Macedo absurdly think that most of the time, therefore, (a) the couple's genitals are not reproductive organs ${ }^{122}$ _except perhaps in the sense that

119. That is, a man and a woman who can engage in marital intercourse (what Koppelman has to call "penile-vaginal" intercourse) but who cannot thereby procreate (e.g. because the wife's tubes are irreversibly tied, or her uterus is missing).

120. The sex acts in question are generally referred to vaguely by Koppelman (e.g. "sexual conduct" (p. 2), "sex" (p. 2), "pleasuring one another sexually" (p. 62)), but sometimes more specifically ("anal or oral sex" (p. 67)), and sometimes as "sexual intercourse" (p. 62, p. 93). "Sexual intercourse," more properly speaking, is the kind of sex act which, today as always, is required in law to consummate a marriage, and persons of the same sex are simply incapable of engaging with each other in that kind of act.

121. Koppelman greatly understates this when, in noting that "normal women...are only capable of reproducing during a small part of their lives", he adds "there is nothing abnormal about menstruation and menopause" (p. 76, n. 105). For there is also nothing abnormal about the fact that ovulation occurs only about once a month, and the woman's capacitated ovum is capable of being fertilized for not more than about one day. Given the limited time that sperm can survive, the couple as such is fertile-not more than four or five days in each more or less monthly cycle.

122. See e.g. (p. 66): "A sterile person's genitals are no more suitable for generation than an unloaded gun is suitable for shooting. ... the only aspect of material reality that matters is whether the gun, as it now is, is in fact capable of killing" (emphasis added). Koppelman sometimes, inconsistently, speaks as if they are not reproductive if and only if they belong to people who are completely sterile e.g. "a woman whose diseased uterus was removed" (p. 66). 
a dead man's dead heart "is still a heart"! (p. 76)-and (b) the couple's intercourse cannot be of a reproductive kind. The same line of thought also drives these writers towards the equally arbitrary conclusion ${ }^{123}$ that a man and a woman can never be biologically united-only sperm and egg can be biologically united! While in this reductivist, word-legislating mood, one might declare that sperm and egg unite only physically and only their pronuclei are biologically united. But it would be more realistic to acknowledge that the whole process of copulation, involving as it does the brains of the man and woman, their nerves, blood, vaginal and other secretions, and coordinated activity (such that conception is much less likely to result from rape) is biological through and through. The dualism embraced by Koppelman and Macedo ${ }^{124}$ neatly shows how far humanness itself - the radical unity of body ("biology"), sense, emotion, reason, and will-becomes unintelligible once one loses one's grip on the way in which a marital sexual act, uniting $u s^{125}$ in a particular bodily (and therefore biological) way can really actualize, express, and enable us truly to experience something as intelligent and voluntary as a freely chosen commitment to serving each other as complementary friends in a form of life adapted, by its permanence and exclusivity, to serving also (if fortune so provides) our children as the living embodiments and fruit peculiarly appropriate to our kind of (comm)union. ${ }^{126}$

Sexual acts which are marital are "of the reproductive kind"127 because

123. See p. 67 at $n$. 77: "Macedo ... could ...still dispute that the spouses unite biologically...". Koppelman defensively adds that Macedo "could also concede that the biological union takes place, but deny that this union has intrinsic value." The addition and envisaged concession are significant, since the "intrinsic value" of the biological union in $a$ genuinely marifal act is intrinsic not in the fallacious sense that value can be deduced from biological facts, nor in the ethically false sense that any biological union between a man and a woman is valuable or morally good, but in the logically and ethically valid sense that, by being a union of the reproductive kind, that union can be part of the instantiating of the intrinsic and basic human good (value) of marriage.

124. See also the response to Macedo on this point by George and Bradley, op. cit. supra n. 33 at 311 n. 32.

125. The organic unity which is instantiated in an act of the reproductive kind is not so much the unity of penis and vagina (as my inexact wording in the footnote quoted at p. 66 at $\mathbf{n} .75$ incautiously suggests) but rather the unity of the man and the woman-the unity which is consummated in their intentional, consensual act of uniting those genital organs in seminal emission/reception in the woman's reproductive tract.

126. See further George and Bradley, op. cit., supra n. 33 at 304 text and n. 16.

127. In Aquinas, "act of the generative type" is often the correct translation of actus [or opus] generationis (as used in the context of human sexual activity). This is put beyond doubt by Quodl. XI q. 9 a. 2 ad 1: "old people are 'frigid' not in relation to the generative type of act, but in relation to the generation of offspring, and so since they can have sexual intercourse, their marriage is not dissolved (senes sunt frigidi non quidem ad actum generationis, sed ad generationem prolis, et ideo, cum possint camaliter copulari, non solvitur matrimonium\}." For other passages in which actus generationis is being used as a kind of synonym for sexual intercourse of the behaviorally standard kind, and where actual generation 
in willing such an act one wills sexual behavior which is intended as and is (a) the very same bodily and behavior as causes generation (intended or unintended) in every case of human sexual reproduction, and (b) the very same as one would will if one were intending precisely sexual reproduction as a goal of a particular marital sexual act. This kind of act is a "natural kind," in the morally relevant sense of "natural," not (as Koppelman supposes) ${ }^{128}$ if and only if one is intending or attempting to produce an outcome, viz. reproduction or procreation. Rather it is a distinct rational kind-and therefore in the morally relevant sense a natural kind-because (i) in engaging in it one is intending a marital act, (ii) its being of the reproductive kind is a necessary though not sufficient condition of it being marital, and (iii) marriage is a rational and natural kind of institution. One's reason for action-one's rational motive-is precisely the complex good of marriage.

For: marriage is rational and natural primarily because it is the institution which physically, biologically, emotionally, and in every other practical way is peculiarly apt to promote suitably the reproduction of the couple by the generation, nurture, and education of ultimately mature offspring. The version of "gay" ideology defended by Koppelman, Macedo, and others who claim that sex acts between persons of the same sex can be truly marital, and that to perform such acts two such persons can indeed marry each other, suggests (without clearly affirming) that homosexual sex acts should be evaluated by focusing upon this sort of activity of this sort of couple. Koppelman (p. 62) adopts Sidney Callahan's claim that when engaged in "with a faithful partner," such same-sex sex acts "produce...intense intimacy, bodily confirmation, mutual sanctification, and fulfilling happiness." If it is a trifle careless of Koppelman to accept that "mutual

seems entirely beside the question, see e.g. IV Sent. d. 42 q. 1 a. 2 c ("cognatio carnalis non contrahitur nisi per actum generationis completum; unde etiam affinitas non contrahitur nisi sit facta conjunctio seminum, ex qua potest sequi carnalis generatio"); IV Sent. d. 32 q. 1 a. 5 sol. 3c ("cum mulier habeat potestatem in corpus viri quantum ad actum generationis spectat, et e converso; tenetur unus alteri debitum reddere quocumque tempore et quacumque hora..."); IV Sent. d. 33 q. 3 a.l c ("virginitas...integritas quaedam est; unde per privationem corruptionis dicitur, quae in actu generationis accidit; ubi triplex corruptio est. Una corporalis tantum, in hoc quod claustra pudoris franguntur. Alia spiritualis et corporalis simul, ex hoc quod per decisionem et motum seminis, in sensu delectatio generatur. Tertia est spiritualis tantum, ex hoc quod ratio huic delectationi se subjicit, in qua integritatem perdit quantum ad actum...") (Thus the significant and per se effects of this actus generationis do not include generation, but do include the pleasurable ejaculation and flow of semen, which is one of the reasons Aquinas gives, in this passage, for judging that intercourse is one way in which a man's or a woman's state of virginity is ended]. The very idea of a generative kind of act, or act per se apt for generation, is articulated-albeit not in those words-in e.g. Mal. q. 15 a. 2 ad 14 and ScG III c. 122 n. 5.

128. See Koppelman's discussion (especially around footnotes 79 and 80) of what outcomes one can and cannot intend to produce with the unloaded gun whose wielding Koppelman vainly tries to analogize to marital intercourse. 
sanctification" is "produced" by sex acts in a universe he proclaims to be "disenchanted," much more interesting is his failure to explain why this and the other effects allegedly "produced" by sex acts depend upon the faithfulness of one's partner, or partners, ${ }^{129}$ and, I assume, upon one's own faithfulness.

The fact is that "gay" ideology, even in the sanitized Koppelman/Macedo version, 130 has no serious account whatever of why faithfulness-reservation of one's sex acts exclusively for one's spouse-is an intelligible, intelligent, and reasonable requirement. Only a small proportion of men who live as "gays" seriously attempt anything even resembling marriage as a permanent commitment. Only a tiny proportion seriously attempt marital fidelity, the commitment to exclusiveness; the proportion who find that the attempt seems to make sense, in view of the other aspects of their "gay identity," is even tinier. ${ }^{131}$ Thus, even at the level of behavior-i.e. even leaving aside its inherent sterility-gay "marriage," precisely because it excludes or makes no sense of a commitment utterly central to marriage, is a sham. ${ }^{132}$

129. Not yet disentangled from the Catholic teaching on marriage she is "changing her mind" away from, Callahan just takes it for granted that there is to be just one same-sex partner. (The same must be said of Paul Weithman in the article quoted and relied upon by Koppelman, p. 70 at n. 89; similarly Michael Perry as cited in n. 88.) The assumption has no rational ground. And see n. 136 below.

130. Incompletely sanitized: for sometimes the veil of solemnity about "same-sex marriage" slips, and the underlying, and more coherent, gay ideology peeps through: "Why cannot sex at least sometimes be one more kind of harmless play?" (p. 89). And see n. 132 below.

131. See the surveys and discussions by homosexual sociologists and writers cited in Germain Grisez, The Way of the Lord Jesus vol. 3 Difficult Moral Problems (Quincy, IL: Franciscan Press, 1997) 108, 110. Koppelman, "Three Arguments for Gay Rights," Michigan L. Rev. 95 (1997) at 1665 approvingly reports research indicating that "among couples together for more than 10 years, ... 30\% of husbands... and $94 \%$ of gay men reported at least one instance of nonmonogamy [scil. sexual infidelity]." But he understates the contrast revealed by that research: of that $94 \%$, over $80 \%$ had been unfaithful during the 12 months prior to the research (whereas only a minority of the unfaithful minority of husbands had been unfaithful in the same period), indicating that the infidelities of even long-term homosexual male couples are overwhelmingly more frequent. Philip Blumstein \& Pepper Schwartz, American Couples (New York: Morrow, 1983), 276. Blumstein and Schwartz soberly conclude (ibid., 275) that for all homosexual couples, "as the relationship goes on, virtually'all gay men have other sexual partners." Note also that when Blumstein and Scwhartz followed up their large cohort of couples eighteen months after the main survey, more than one in five of the lesbian couples had meanwhile broken up (compared with one in twenty of the married couples): ibid., 308.

132. The Fall 1997 issue of The Harvard Gay \& Lesbian Review: A Quarterly Joumal of Arts, Letters, \& Sciences (vol. IV no. 4) has as its theme "same-sex marriage" [SSM]. The editor-in-chief assembled five essays on the theme, and himself conducted a searching and sympathetic interview with a leading proponent, Andrew Sullivan. In his editorial he then says: 
And this reality is just what ethical reflection would lead one to expect. The reason why marriage requires not just "a commitment to each other" 133 but commitment to permanence and exclusiveness in the spouses' sexual union is that, as a morally coherent institution or form of life, it is fundamentally shaped by its dynamism towards, appropriateness for, and fulfilment in, the generation, nurture, and education of children who each can only have two parents and who are fittingly the primary responsibility (and object of devotion) of those two parents. Apart from this orientation towards children, the institution of marriage, characterized by marital fides (faithfulness), would make little or no sense. ${ }^{134}$ Given this orientation, the marital form of life does make good sense, and the marital

The attempt to sanitize SSM for tactical reasons has resulted in a kind of studied silence on the subject of sex... we end up soft-pedaling sex in favor of "commitment." And while the discussion of sex within marriage has been avoided, the discussion of non-marital and extra-marital sex has also largely been missing, at least in our "official" pronouncements and lobbying efforts in Washington and Hawaii. And yet, in talking about an institution that most Americans define as fidelity to a single partner for a lifetime, how can we avoid discussing sexual promiscuity and serial monogamy and the myriad ways that long-term gay couples have defined their relationships. ... Gabriel Rotello and Andrew Sullivan ... have regarded SSM as a possible antidote to gay male promiscuity and wildness - which it may well be, though I think it's just as likely that gay marriages would liven up the institution as submit to its traditional rules (suits me fine). We also might examine just why we feel we need to sidestep the issues of sex and promiscuity and alternative partnering... (p. 4).

See likewise Gabriel Rotello, "Creating a New Gay Culture: Balancing Fidelity and Freedom," The Nation, 21 April 1997:

The antimarriage sentiment in the gay and lesbian political world has abated in recent years, and the legalization of same-sex marriage is now an accepted focus of gay liberation. Yet....most advocates of same-sex marriage...are generally careful not to make the case for marriage, but simply for the right to marriage. This is undoubtedly good politics, since many if not most of the major gay and lesbian organizations that have signed on to the fight for same-sex marriage would instantly sign off at any suggestion that they were actually encouraging gay men and lesbians to marry.

\section{(emphasis in original)}

133. On the marriage-dissolving significance of the fact that many or even most American couples in recent years have married using their own home-made vows, which characteristically leave in shadow the vow of life-long union and replace it with some vow or affirmation of "commitment," see David Blankenhom, "I Do," First Things no. 77 (November, 1997) 14 15.

134. Nussbaum and Dover (supra n. 91 at 1650-51) do not like "Finnis' narrow definition of the marital relationship"-i.e. the definition that has been normative and central for our whole civilization (and not only ours)-but cannot agree even between themselves on a coherent alternative. Dover (speaking of himself in the third-person) "feels that deliberate joint procreation is qualitatively different from nonprocreative sex and that the latter is, so to speak, playing at procreation. (Play, however, may be very important.) He is therefore uneasy about the idea of homosexual marriage." 
sexual acts which actualize, express, and enable the spouses to experience that form of life make good sense, too.

Moreover, a man and a woman who can engage in precisely the same marital acts with precisely the same behavior and intentions, but who have reason to believe that in their case those very same acts will never result in children, can still opt for this form of life as one that makes good sense. Given the multiple and profound bodily, emotional, intellectual, and volitional complementarities with which that combination of factors we call human evolution has equipped us as men and women, such a commitment can be reasonable ${ }^{135}$ as a participation in the good of marriage which these infertile spouses can rightly wish to have instantiated more fully than they can. To repeat: they do really participate in it because they can make every commitment and can form and carry out every intention that any other married couple need make, form, and carry out in order to be validly married and to fulfil all their marital responsibilities. By their model of fidelity within a relationship involving acts of the reproductive kind (and no other sex acts), these infertile marriages are, moreover, strongly supportive of marriage as a valuable social institution.

But same-sex partners cannot engage in acts of the reproductive kind, i.e. in marital sexual intercourse. For them the permanent, exclusive commitment of marriage - in which bodily union in such acts is the biological actuation of the multi-level (bodily, emotional, intellectual, and volitional) marital relationship-is inexplicable. Of course, two, three, four, five or any number of persons of the same sex can band together to raise a child or children. That may, in some circumstances, be a praiseworthy commitment. It has nothing to do with marriage. Koppelman and Macedo remain discreetly silent on the question why the same-sex "marriage" they offer to defend is to be between two persons rather than three, four, five, or more, all engaging in sex acts "faithfully" with each other. They are equally silent on the question why this group sex-partnership should remain constant in membership, rather than revolving like other partnerships. Koppelman devises an "account of the good of marriage" by the easy-going procedure of asking us to "consider the possibility that there is an intrinsic good pursued, distinct in kind from ordinary friendship or ordinary pleasure, but of which pleasure is a necessary component"- a good pursued by "sexual activity" which "as Paul Weithman has observed...could "constitute two people as a social unit...".136 Should he not also have asked us to

135. Those, however, who search out infertile spouses, choosing them precisely for their infertility, may well be manifesting the kind of contempt for the marital good which Philo Judaeus condemned in the rather confused passage from which Koppelman (p. 64 at n. 61) and Boswell quote some over-heated fragments.

136. Page 70 at $n .89$. The good is said (id.) to be the good of marriage and the "function or characteristic activity" of the postulated social unit is said to be "to promote [these two people's] friendship and love through special acts of physical intimacy and tenderness." As 
"consider the possibility" that there is also an "intrinsic good pursued" by the "sexual activity" which "constitutes three people" or "one man and his dog" as "social units"-or two people as a six-month "social unit"? The list of possibilities to consider while we are devising such "accounts" or forms of "marriage" has no real end.

Those who propound "gay" ideology or theories of same-sex marriage or "sexual activity" have no principled moral case to offer against (prudent and moderate) promiscuity, indeed the getting of orgasmic sexual pleasure in whatever friendly touch or welcoming orifice (human or otherwise) one may opportunely find it in. In debate with opponents of their ideology or theories, some of these proponents are fond of postulating an idealized (twoperson, lifelong...) category of relationship, and of challenging their opponents to say how relationships of such a (not too carefully delimited) kind differ from marriage at least where husband and wife know themselves to be infertile. As I have argued, the principal difference is simple and fundamental: the artificially delimited category named "gay marriage" or "samesex marriage" corresponds to no intrinsic reason or set of reasons at all. When we realize that-and why-the core of marriage is fides, the stringently exclusive commitment whose rationale and implications for sexual activity's integrity, purity, and reasonableness were well understood by Aquinas, we realize that - and why - the world of same-sex partnerships (in the real world outside the artifice of debate) offers no genuine instantiations, equivalents, or counterparts to marriage, and so very few whole-hearted imitations. ${ }^{137}$ Marriage is the coherent, stable category of relationships,

a prominent advocate of same-sex "marriage" says: "If the law of marriage can be seen as facilitating the opportunities of two people to live an emotional life that they find satisfactory-rather than imposing a view of proper relationships - the law ought to be able to achieve the same for units of more than two." David L. Chambers, "What If? The Legal Consequences of Marriage and the Legal Needs of Lesbian and Gay Male Couples," Michigan L. Rev. 95 (1996) 447, 490-1.

137. This is not to deny that some people try to make their sex acts with persons of the same sex acts of friendship, as I like Grisez, George, Lee, and Bradley have often said. Koppelman is indignant about a fragment he quotes (p. 92, n. 163) from Grisez ("sexual intercourse is not chosen by sodomites in preference to conversation and mutually beneficial acts because it is the more expressive means of communicating good will and affection. Rather, it is chosen because it provides subjective satisfactions otherwise unavailable.") This claim, says Koppelman with approval, "has struck many readers as a gross libel on many committed same-sex relationships." But the real libel is Koppelman's claim that this fragment is "all [Grisez] says in response to the argument that sodomitic sex may be a way of manifesting friendship and affection." By slicing off the first words of the fragment ("However, just as with fornicators..."), Koppelman not only leaves his readers to infer that Grisez has a bias against or blindspot about homosexuals, but also, more importantly, hides the fact that the deleted words about fornicators are a reference to Grisez's extended argument on the preceding pages (652-3) in response to an objector who asks: "what if.. the [fornicating] couple are interested, not in marital communion, but only in some other sort of real and intimate communion, such as friendship, which they presently enjoy and which their sexual intercourse nurtures by communicating good will, affection, and so on?" Grisez's 
activities, satisfactions, and responsibilities which can be intelligently and reasonably chosen by a man together with a woman, and adopted as their demanding mutual commitment and common good, because its components respond and correspond fully reasonably to that complex of interlocking, complementary good reasons.

Plato, Aristotle, ${ }^{138}$ and other great philosophers, like the mass of ordinary participants in the tradition of civilized life, understand that complex as constitutive of (the good of) marriage. And I have been arguing that true and valid sexual morality does no more, and no less, than unfold what is involved in understanding, promoting, and respecting (not violating) that basic human good, and what are the conditions for instantiating that common good of the two spouses in a real, non-illusory way, integrating all the levels of their human reality, in the marital act.

reply begins by accepting that "psychologically healthy couples who fornicate ordinarily do desire at least something of the experience of marital intimacy" (652); and he explicitly says the same of the same-sex couple on the page (654) from which Koppelman quoted a fragment. Grisez's response to the objection proceeds with a careful argument to show why, seeing that "precisely insofar as intercourse is not chosen for any aspect of [the good of marriage], it does not communicate anything definite by itself," and that it is indeed far less expressive than other modes of communication commonly used by friends, the true motive for choosing it is "sexual desire and the pleasure of satisfying it." Since I am not in this article elaborating the arguments from self dis-integrity and illusory good, I need not set out the whole argument (which begins on p. 649). Suffice it to underline that Grisez is not denying "the experience of intimacy of the partners in sodomy" (653), but is giving reasons for judging that the experience "cannot be the experience of any real unity between them." $A$ reasoned argument about what is real and what is illusory in what is granted to be an actual experience cannot be any kind of libel.

138. "Human beings are by nature more conjugal than political": Nicomachean Ethics VIII 1162a17-18. Nussbaum characteristically asserts that "Marriage is mentioned only twice in the entirety of the Nicomachean Ethics: at 1123al as the occasion for an especially big party, and at 1165 al 8 as an occasion, like a funeral, to which one would want to invite one's relatives." Virginia L. Rev. 80 (1994) at 1583 n. 294. 